\title{
WHAT THE NEW SUPREME COURT HAS DONE TO THE OLD LAW OF NEGLIGENCE
}

\author{
SIDNEY S. AIDERMAN*
}

In I940, General Charles De Gaulle, in his declaration from London, made famous in history his ringing statement that "France has lost a battle; she has not lost the war." Contemporaneously, President Franklin D. Roosevelt was steadily winning a war, the first battle of which he had lost when the Senate of the United States, in July, I937, in expression of an aroused public sentiment for the preservation of an independent judiciary, soundly defeated his famous court-packing plan. But, between June, I937, and January, I943, as the result of deaths and retirements among the "nine old men"1 on the "old Supreme Court," President Roosevelt had the opportunity to, and did, substantially reconstitute the Court, by appointing to it eight new Associate Justices, ${ }^{2}$ all Democrats and supporters of his "New Deal."

Justice Harlan Fiske Stone, promoted by President Roosevelt to the office of Chief Justice, was a Republican, originally appointed to the Court by President Coolidge, but he was greatly admired by President Roosevelt. In his "fireside chat" of March 9, I937, and in the testimony by his Attorney General, Homer S. Cum-

*A.B. 1913, Trinity College; graduate, 19r6, Trinity College Law School; I919, Ecole de Droit, Sorbonne University, Paris, France. General Solicitor, Southern Railway Company and affiliated lines, 1930-1947; General Counsel, January I, I947 to May 23, 1950, and since then Vice President and General Counsel. Special Assistant to the Attorney General of the United States, r945-r946, serving as Assistant to Mr. Justice Robert H. Jackson, Chief of United States Counsel for the prosecution of the major European Axis war criminals before the International Military Tribunal, Nuremberg, Germany. Trustee of Duke University.

${ }^{2}$ The disrespectful title of a then current book by Drew Pearson and Robert Allen.

2The following were his appointments of new Associate Justices, with indication of the vacancy filled, date of nomination, and date seated on the Court:

(I) Senator Hugo L. Black, of Alabama, in the place of Mr. Justice Willis Van Devanter, retired; nominated August 12, 1937, seated October 4, 1937 (302 U. S. iii (1937)).

(2) Solicitor General Stanley Reed, in the place of Mr. Justice George Sutherland, retired; nominated January $15, x 938$, seated January 31, r938 (303 U. S. iv (1938)).

(3) Professor Felix Frankfurter, of Harvard Law School, in the place of Mr. Justice Benjamin N. Cardozo, deceased; nominated January 5, I939, seated January 30, I939 (306 U. S. iii (r939)).

(4) Mr. William O. Douglas, Chairman of the Securities and Exchange Commission and former professor of law in Columbia University Law School, in the place of Mr. Justice Louis D. Brandeis, retired; nominated March 20, I939, seated April I7, I939 (306 U. S. iii (r939)).

(5) Attorney General Frank Murphy, of Michigan, in the place of Mr. Justice Pierce Butler, deceased; nominated January 4, 1940, seated February 5, 1940 (309 U. S. iii (1940)).

(6) Senator James F. Byrnes, of South Carolina, in the place of Mr. Justice James Clark McReynolds, retired; nominated June 12, I941, seated October 6, I94I (3I4 U. S. iv (I94I)).

(7) Attorney General Robert H. Jackson, of New York, in place of Associate Justice Harlan Fiske Stone, promoted to Chief Justice; nominated June 12, 194I, seated October 6, x94I (314 U. S. iv (I94I)).

(8) Honorable Wiley Rutledge, of Iowa, Associate Justice of the United States Court of Appeals for the District of Columbia, in the place of Associate Justice James F. Byrnes, resigned; nominated January Ix, I943, seated February I5, I943 (318 U. S. iii (I943)).

${ }^{3}$ Fireside Chat on Reorganization of the Tudiciary, in The Publre Papers and Addresses of Frankuin D. Roosevelt (r937-The Constitution Prevails) 129 (Rosenman ed. 194I). 
mings, on the next day, March 10, $1937,{ }^{4}$ the President assured the nation that by his court-packing plan he did not seek the power to appoint justices subservient to him but that he sought only the power to appoint justices fit to sit beside members of the Court who understood modern conditions and who would "think like" Justices Brandeis, Stone, and Cardozo.

On April I2, 1945, Franklin D. Roosevelt died and Vice President Harry S. Truman, former Democratic Senator from Missouri, became President. He engrafted his "Fair Deal" on his predecessor's "New Deal" and has always boasted that he has followed his predecessor's policies. However, he appointed to the Court, as Associate Justice, Senator Harold H. Burton, of Ohio, the first Republican to be named to the Court since the appointment of Chief Justice Hughes by President Hoover in 1930. Mr. Justice Burton was seated October r, I945. President Truman also appointed a Democrat as Chief Justice and two Democrats as Associate Justices, all stalwart supporters of the New Deal and of the Fair Deal. ${ }^{5}$

Thus Presidents Roosevelt and Truman, since August, I937, had made a clean sweep of the old Court and several changes on the new Court. Out of a total of eleven Associate Justices appointed to the Court, only one, Mr. Justice Burton, had been a Republican. One Republican and one Democrat had been appointed Chief Justice.

Fortunately for this country, although a court can be packed with his partisans by a Chief Executive, he cannot keep it packed as a partisan tribunal. He cannot control the decisions of his appointees after they take their oaths as judges and take their seats on an independent Court. Men of intelligence and character, however partisan they may have been politically, when they are appointed to an independent judiciary, became their own masters, do their own thinking, and wrestle with their own consciences, not with the will of the appointing power.

The outstanding example of this was Mr. Justice Holmes. President Theodore Roosevelt appointed him to the Supreme Court for the very purpose of getting one more vote for the Government and hence of controlling decision in the Northern Securities case. The idea that court decisions could be controlled by court appointments seems to have run in the Roosevelt family. It was no patented, exclusive property of the Democratic branch of that family. But, much to Theodore Roose-

'Hearings before the Senate Committee on the Judiciary on S. 1392 (A Bill to Reorganize the ludicial Branch of the Government), 75th Cong., Ist Sess. I6, 32 (1937).

'President Truman's appointments were as follows:

(I) Senator Harold H. Burton, of Ohio, in the place of Associate Justice Owen J. Roberts, resigned; nominated September 18, 1945, seated October I, I945 (326 U. S. iv (1945)).

(2) Honorable Fred M. Vinson, of Kentucky, Secretary of the Treasury, former Democratic Congressman, Associate Justice of the United States Court of Appeals for the District of Columbia, appointed Chief Justice in the place of Chief Justice Stone, deceased; nominated June 6, I946, seated June 24, 1946 (329 U. S. iii (1946)).

(3) Honorable Tom C. Clark, of Texas, Attorney General, in the place of Associate Justice Frank Murphy, deceased; nominated August 2, I949, seated October 3, 1949 (338 U. S. iv (1949)).

(4) Honorable Sherman Minton, of Indiana, Judge of the United States Court of Appeals for the Seventh Circuit, in the place of Mr. Justice Wiley Rutledge, deceased; nominated September I5, 1949, seated October I2, I949 (338 U. S. iv (I949)). 
velt's chagrin, his special appointee, Mr. Justice Holmes, dissented from the holding, by a bare majority of the Court, in favor of the government in the Northern Securities case ${ }^{6}$ and it was in that dissent that he made one of his most famous statements:

Great cases like hard cases make bad law. For great cases are called great, not by reason of their real importance in shaping the law of the future, but because of some accident of immediate overwhelming interest which appeals to the feelings and distorts the judgment. These immediate interests exercise a kind of hydraulic pressure which makes what previously was clear seem doubtful, and before which even well settled principles of law will bend.

In one of his famous letters to his friend Sir Frederick Pollock, that of February 9, I92I, ${ }^{7}$ Mr. Justice Holmes discussed this incident with complete frankness. $\mathrm{He}$ said:

A good letter from you, just after reading Theodore Roosevelt \& His Time, a class of work that I eschew. Of course I pretty well made up my package about him a good while ago, and I don't think I was too much disturbed by what you admit to and what was formulated by a Senator in his day, thus: "What the boys like about Roosevelt is that he doesn't care a damn for the law." It broke up our incipient friendship, however, as he looked on my dissent to the Northern Securities case as a political departure (or, I suspect, more truly, couldn't forgive anyone who stood in his way). We talked freely later but it never was the same after that, and if he had not been restrained by his friends, I am told that he would have made a fool of himself and would have excluded me from the White House-and as in his case about the law, so in mine about that, I never cared a damn whether I went there or not. He was very likeable, a big figure, a rather ordinary intellect with extraordinary gifts, a shrewd and I think pretty unscrupulous politician. He played all his cards-if not more. R. i. p.

On the bench, Holmes wore no man's collar. He bowed to no "hydraulic pressure" of "immediate overwhelming interest." He wrestled with no angel but his own judicial conscience.

Nevertheless, men remain human beings after they don judicial robes. Human beings cannot completely divorce themselves from their previous training, environment, activities, and sympathies, or from what Chief Justice Stone called their "previous economic predilections." While neither President Roosevelt nor President Truman could have controlled, if either had wanted to, any particular decision of any one of his appointees to the Court, all the world knows that the new Court, as reconstituted after I937, has substantially revolutionized and rewritten large parts of the law of the land, from constitutional law to venue, if not from admiralty to zoning. It has overruled precedents of seventy-five years' standing. Whether this has been a good or a bad revolution, history will judge. It would take a treatise of several volumes to describe the changes in the law by the decisions in this period.

\footnotetext{
${ }^{\circ}$ Northern Securities Co. v. United States, 193 U. S. 197, 400-40I (1904).

${ }^{7}$ See II Holmes-Pollock LetTers 63-64 (I94I).
} 
A pertinent comment on this revolution in the law by the new Supreme Court has just come from the pen of Mr. Justice Jackson, as this paper goes to press, in his separate opinion in Brown v. Allen, decided February 9, I953, in which he said (73 Sup. Ct. 397, 424):

Rightly or wrongly, the belief is widely held by the practicing profession that this Court no longer respects impersonal rules of law but is guided in these matters by personal impressions which from time to time may be shared by a majority of Justices. Whatever has been intended, this Court also has generated an impression in much of the judiciary that regard for precedents and authorities is obsolete, that words no longer mean what they have always meant to the profession, that the law knows no fixed principles.

Again, in the same opinion, Mr. Justice Jackson said (id. at 427):

There is no doubt that if there were a super-Supreme Court, a substantial proportion of our reversals of state courts would also be reversed. We are not final because we are infallible, but we are infallible only because we are final.

Finally, in the same opinion, he said (id. at 430) :

But I know of no way that we can have equal justice under law except we have some law.

It is the limited purpose of this paper to show what the newly constituted Supreme Court of the United States, in the decade since I942, by its decisions under the Federal Employers' Liability Act, ${ }^{8}$ has done to the general law of negligence as settled by long lines of decisions by the "old Court."

I

\section{The Law of Negligence Under the Old Court}

Under the old Court, its decisions under the Federal Employers' Liability Act and related statutes had been an important unifying influence in the development of the general law of negligence. The Supreme Court has no general jurisdiction over cases involving the general law of negligence. It has jurisdiction, in general, only where negligence cases arise under federal laws and that, for all present purposes, means cases arising under the FELA and acts immediately related to it. But in that narrow field the Supreme Court, up to the time of the election of President Roosevelt in 1932, and, indeed, up to the time when he had effectively reconstituted the personnel of the Court, in I942, had enounced a well-settled and consistently applied set of rules of the law of negligence which had an important influence for uniformity in the development of the general body of negligence law, as enounced and applied by state and lower federal courts, comparable to the influence which its decisions had had, say, in the general fields of the law of negotiable instruments and of insurance contracts, suretyship, trusts, etc.

Since President Roosevelt accomplished his purpose of completely packing the Court, in I942, the Court's decisions under the FELA have demonstrated an in-

${ }^{8} 35$ Stat. 65 (I908), as amended, 45 U. S. C. $\$ \$ 5 I-60$ (1946). 
creasing tendency to repudiate that well-settled body of the law of negligence, departing either expressly or usually only sub silentio from former unanimous holdings of the Court in the fundamental respect of holding that any plaintiff's case under the FELA must be submitted to the jury and that the jury's verdict must be binding as to liability, no matter how absent any judicially recognizable probative evidence that the defendant was negligent and that such negligence was the proximate cause of plaintiff's injury or death, no matter how purely speculative or conjectural that evidence might be, and no matter how clearly and convincingly the evidence might have proved that the injured or deceased employee's own negligence was the sole, efficient cause, the causa causans, of his own injury or death.

Since President Truman again began to revamp the Court, by his own appointments, beginning with his appointment of the first Republican since President Hoover's administration, Mr. Justice Burton, in I945, there has been a slight but observable tendency to curb that trend and to take some small steps in the direction of a return to the formerly well-settled principles of the law of negligence. How far that changed trend may go nobody can predict. At least a few cases have been won by railroads since Mr. Justice Burton was seated on October I, r945. For a period of five years, from the decision in the Brady case ${ }^{9}$ on December 20, I943, until the decision in Eckenrode v. Pennsyluania $R . R .{ }^{10}$ no railroad ever won a case under the FELA in the Supreme Court. Every case was won by the plaintiff. It can hardly be supposed that in that period no meritorious case was ever argued to the Court by any railroad.

Under the decisions of the old Court the following principles were well settled under long lines of cases:

The FELA does not undertake to define negligence or proximate cause. What is negligence thereunder is a matter to be determined by the application of the principles of the common law, as applied by the Supreme Court under this federal statute. ${ }^{11}$

In such cases, only by a uniform federal rule as to the necessary amount of evidence may litigants under the Federal Act receive similar treatment in all states. ${ }^{12}$

In these cases, it is for the United States Supreme Court to examine the record to determine whether, as a matter of law, there is sufficient evidence to sustain a jury finding of negligence as the proximate cause of the injury or death. ${ }^{13}$

When a state's jury system requires its court to determine the sufficiency of the evidence to support a finding of a federal right to recover, the correctness of this ruling is a federal question, reviewable by the Supreme Court of the United States. ${ }^{\mathbf{1 4}}$

${ }^{8}$ Brady v. Southern Ry., 320 U. S. 476 (I943).

10 3.35 U. S. 329 , decided Nov. $15,1948$.

${ }^{11}$ Southern Ry. v. Gray, 24 I U. S. 333 (1916); Tiller v. Atlantic Coast Line R. R., 318 U. S. 54, 57 (1943).

${ }_{12}$ Chicago, M. \& St. P. Ry. v. Coogan, 271 U. S. 472, 474 (1926); Western \& Atlantic R. R. v. Hughes, 278 U. S. 496, 498 (1929); Brady v. Southern Ry., 320 U. S. 476, 479 (1943).

${ }^{13}$ Atchison, T. \& S. F. R. R. v. Saxon, 284 U. S. 458 (1932); Chicago Great Western R. R. v. Rambo, 298 U. S. 99 , 102 (1936).

14 Brady v. Southern Ry., 320 U. S. 476, 479 (1943). 
The weight of the evidence under the FELA must be more than a scintilla before the case may be properly left to the discretion of the trier of the facts, usually the jury, and no rule of state law for the submission of a mere scintilla to the jury can be allowed to stand under the Federal Act. ${ }^{15}$

Evidence sufficient to raise only a mere speculation or conjecture as to negligence of the defendant or that such negligence was the proximate cause of injury or death is not sufficient to support a verdict finding liability to the plaintiff. ${ }^{16}$

When the evidence is such that without weighing the credibility of the witnesses there can be but one reasonable conclusion as to the verdict, the trial court should determine the proceeding by non-suit, directed verdict or otherwise in accordance with the applicable practice, state or federal, without submission to the jury, or by judgment notwithstanding the verdict. By such direction of the trial the result is saved from the mischance of speculation over legally unfounded claims. ${ }^{17}$

The same rule as just stated applies to questions of proximate cause as well as to questions of negligence. ${ }^{18}$

The bare possibility that an employee might be injured in a particular way or by a particular condition or operation is not sufficient as a basis of employer liability and an employer cannot be held to the duty of guarding against a device being employed by an employee in a dangerous way "so unusual, so contrary to the purpose" for which the device is furnished that due care would not lead the employer to expect such a use and injury. ${ }^{19}$

Events too remote to require reasonable provision need not be anticipated. ${ }^{20}$

Liability under the FELA arises from negligence, not from injury. And that negligence must be the cause of the injury. ${ }^{21}$

The carrier's negligence must be a link in an unbroken chain of reasonably forseeable events. ${ }^{22}$

It is fortuitous that two companion cases in 1932 and a case in December, I943,

${ }^{15}$ Baltimore \& Ohio R. R. v. Groeger, 266 U. S. 52I, 524 (1925); Western \& Atlantic R. R. v. Hughes, 278 U. S. 496,498 (r929); Brady v. Southern Ry., 320 U. S. 476,479 (r943).

${ }_{10}$ Chicago Great Western R. R. v. Rambo, 298 U. S. 99, 102 (1936); Brady v. Southern Ry., 320 U. S. $476,479-480$, and cases and authorities there cited, for which see note I 7 , infra.

${ }_{17}$ Brady v. Southern Ry., 320 U. S. 476, 479-480 (r943), citing the following: Parks v. Ross, II How. 362,373 (U. S. I850); Coughran v. Bigelow, I64 U. S. 301,307 (I896); Anderson v. Smith, 226 U. S. 439 (1913); Seaboard Air Line Ry. v. Padgett, 236 U. S. 668, 673 (1915); Baltimore \& O. R. R. v. Groeger, 266 U. S. $52 \mathrm{I}$ n. I (r925); Gunning v. Cooley, 28I U. S. 90,93 note (I930); Pence v. United States, 3 I6 U. S. 332 (r942); Galloway v. United States, 3rg U. S. 372 (r943); 9 Wigmore, Evidence $\$ \$ 2494$ et seq. (3d ed. 1940$)$.

${ }_{18}^{8}$ Brady v. Southern Ry., 320 U. S. 476,483 (I943), citing: St. Louis-San Francisco Ry. v. Mills, 27 U. S. 344 (1926); New York Central R. R. v. Ambrose, 280 U. S. 486 (I930); Atchison, T. \& S. F. Ry. v. Toops, 28x U. S. $35 x$ (x930); Baltimore \& Ohio R. R. v. Tindall, 47 F. 2d I9 (7th Cir. I93I); Texas Gulf Sulphur Co. v. Portland Gas Light Co., 57 F. 2d 8ox (Ist Cir. 1932). Cf. Story Parchment Co. v. Paterson Co., 282 U. S. 555, 556 (193I). $(1876)$.

${ }^{10}$ Brady v. Southern Ry., stpra, at 483, citing Milwaukee \& St. Paul Ry. v. Kellogg, 94 U. S. 469, 475

${ }_{20}$ Brady v. Southern Ry., supra, at $483-484$.

${ }^{21}$ Brady v. Southern Ry., supra, at 484 , citing Tiller v. Atlantic Coast Line R. R., 3I8 U. S. 54, 67 (1943).

${ }_{22}$ Brady v. Southern Ry., stipra, at 484 n. 3, citing The Squib Case, 2 W. Bl. 892 and Y Cooley oN TORTs $\$ 50$ n. 25 (4th ed. I932) and collected cases. 
each presented to the Court on behalf of the railroad by the present writer, mark the boundaries of the period within which President Roosevelt was filling the Court with his own appointees and also are landmarks in the settled law of the FELA as declared by the old Court and as above summarized.

The companion cases in 1932 were Southern Ry. v. Youngblood, ${ }^{23}$ and Southern Ry. v. Dantzler, ${ }^{24}$ both decided on May I6, I932, by a unanimous Court, and reversing verdicts and judgments for plaintiffs which had been affirmed by the Supreme Court of South Carolina. The 1943 case was Brady v. Southern $R y .{ }^{25}$ in which the Court, in a five-to-four decision, the majority opinion written by Mr. Justice Reed and concurred in by Chief Justice Stone and by Justices Roberts, Frankfurter, and Jackson, affirmed a judgment of the Supreme Court of North Carolina which had reversed a jury verdict and trial court judgment for the plaintiff on the ground that there was no sufficient evidence of employer negligence as proximate cause of the death of plaintiff's intestate to have been submitted to the jury.

All three of those cases involved the same principles of law. The two cases in I932 were unanimous decisions. The Brady case in I943, however, was a five-to-four decision, with Justices Black, Douglas, Murphy, and Rutledge dissenting. It represents the crystallization of a consistent bloc of those four Justices, who always voted together for the plaintiff and against the railroad in every case under the FELA, so long as those four were on the Court together. They more and more, after that case, succeeded in drawing the vote of one or more other Justices to their views, so that the Brady case was the last case that any railroad ever won during the next five years after the Brady case. Their position was that every FELA case should be submitted to the jury and that the jury's verdict should be binding, regardless of how purely speculative or conjectural the evidence of negligence and proximate causation might be and regardless of how unforeseeable the particular occurrence might have been.

Their philosophy seems to have been that every railroad employee injured, and that the dependents of every railroad employee killed, in an industrial accident should be compensated, if a jury sees fit to award them compensation, as surely as if a workmen's compensation act applied, and that a trial judge has no function to take any case from a jury or to set aside a verdict or render judgment notwithstanding the verdict, on his judicial determination that the evidence is insufficient to support a verdict as to negligence.

The holdings by the unanimous Court in the Youngblood and Dantzler cases in $x 932$ and by the majority of the Court in the Brady case in 1943 are so wholly in accord with the settled principles of negligence law as above summarized, and the dissenting opinion in the Brady case joined in by the bloc of Justices Black, Douglas, Murphy, and Rutledge so completely foreshadows what the new Court was to do to that negligence law in the next ensuing decade, that it is well to pause for a moment to consider those three cases.

${ }_{23}^{286}$ U. S. 3 I3 (I932).

24 286 U. S. 318 (1932).

${ }^{25} 320$ U. S. 476 (I943). 
Youngblood was the conductor and Dantzler was the engineer of a relief locomotive running light, on a single track railroad, under train orders. They of course were together in the cab of the locomotive and were acting together. They got a meet order, each receiving a written copy, to take a siding to meet and be passed by an extra train operating in the opposite direction. They read the meet order in the presence of the fireman and all three were clearly advised as to what they were ordered to do. The dispatcher and the operator intended to give them a further oral warning to the same effect as the meet order, but this was not done. Nevertheless, the written meet order they had was never revoked or modified and there was nothing that indicated to them any suggestion of a revocation or even of a repetition of the meet order.

They violated their meet order, failed to take the siding, collided with the opposing superior train, and were killed. The meet order they violated was found on the body of each. Their respective administratrices sued the railroad under the FELA. Recoveries in their favor were affirmed by the Supreme Court of South Carolina ${ }^{28}$ on the theory that it was negligence on the part of the dispatcher and the operator not to give to them the added oral warning, which they had intended to give, in addition to but to the same effect as the written order they had received.

On certiorari, the Supreme Court of the United States reversed both cases, by unanimous decision. The principal opinion was written in the Youngblood case. After stating the facts and the opposing contentions, the Court said: ${ }^{27}$

The case comes to this: that respondent's intestate had clear and definite orders which if obeyed would have avoided the accident and the disobedience whereof was the sole efficient cause of his death. As said in Unadilla Valley Ry. Co. v. Caldine, 278 U. S. I39, I42:

"A failure to stop a man from doing what he knows that he ought not to do, hardly can be called a cause of his act. Caldine had a plain duty and he knew it. The message would only have given him another motive for obeying the rule that he was bound to obey."

The record is destitute of any evidence of negligence on the part of the petitioners or their servants or agents which was in any degree a cause of the death of respondent's intestate, and there was nothing to submit to the jury.

The Dantzler case was decided on the reasons set out in the Youngblood case. ${ }^{28}$

In the Brady case, the decedent, a brakeman, was killed in a switching movement by a derailment of freight cars which resulted from his failure to remove from the track a derailer before he gave the signal to switch cars into a storage track from the main line track. The purpose of the derailer on the storage track was to prevent cars on the storage track from drifting accidentally onto the main line. Brady had removed the derailer from the track and opened the switch for an immediately previous movement of cars from the storage track to the main line.

${ }^{20}$ Youngblood v. Southern Ry., I66 S. C. I40, I64 S. E. 43I (I93I); Dantzler v. Southern Ry., I66 S. C. 148,164 S. E. 434 (193I).

${ }^{27}$ Southern Ry. v. Youngblood, 286 U. S. 313, 3I7-318 (I932).

${ }^{28}$ Southern Ry. v. Dantzler, 286 U. S. 318 (1932). 
Then he closed the switch for the fatal movement back from the main line into the storage track, but negligently replaced the derailer on the track in position to derail the very movement which he directed by his own signal. He was in sole charge of the switch and the derailer. No other member of the crew was near them. With the derailer left by him in the derail position on the track, he gave the signal for the movement, rode the lead car onto the derailer, and was killed in the inevitable derailment which resulted. He killed himself as surely as if he had loaded and cocked a gun, placed it to his head, and pulled the trigger.

The Supreme Court of North Carolina held ${ }^{29}$ unanimously that there was no evidence of negligence on the part of the railroad, that the sole proximate cause of the death of Brady was his own negligent act in setting the derailer on the track and then signalling the engineer to back the cars against it. It said that the striking of the derailer from the unexpected direction "was so unusual, so contrary to the purpose" of the derailer that provision to guard against such a happening was beyond the requirement of due care. It reversed verdict and judgment for plaintiff.

The Supreme Court of the United States agreed with the North Carolina court's statement, saying, "Bare possibility is not sufficient," and citing Milwaukee \& St. Paul Ry. v. Kellogg. ${ }^{30}$ It further considered two purely conjectural theories of petitioner as to railroad negligence as alleged bases of liability: $(x)$ that there were defects in the track and a negligent failure to equip the derailer with a light; (2) that some employee other than the decedent might have placed the derailer on the track prior to the movement. It held that there was no evidence that the alleged defects of track could have caused the derailment but for the intervening act of decedent in placing the derailer on the track, that there was no evidence that such derailers were ever equipped with lights, that there was no evidence that any other employee placed the derailer on the track, and that Brady's negligence in placing it on the track was the sole efficient and proximate cause of his death, insulating any theorized prior negligence of the railroad as to track conditions.

In its opinion, the Court reviewed, restated, and reaffirmed the controlling principles of law under the FELA as to which the Brady case is cited in the foregoing summary of that law. Under those principles there can be no question that the holding of the Court in the Brady case was right.

The approach of the dissenters is interesting and revealing. The dissenting opinion by Justice Black, concurred in by Justices Douglas, Murphy and Rutledge, starts with this novel statement: ${ }^{31}$

Twelve North Carolina citizens who heard many witnesses and saw many exhibits found on their oaths that the railroad's employees were negligent. The local trial judge sustained their finding. Four members of this Court agree with the local trial judge that the jury's conclusion was reasonable. Nevertheless five members of the Court purport to weigh all the evidence offered by both parties to the suit, and hold the conclusion was unreasonable. Truly, appellate review of jury verdicts by application of a supposed norm of reasonableness gives rise to puzzling results.

${ }^{28}$ Brady v. Southern Ry., 222 N. C. 367,23 S. E. $2 d 334$ (1942).

${ }^{30} 94$ U. S. $469,475(1876)$.

${ }^{31} 320$ U. S. $476,484-485$. 
This revolutionary suggestion is that judicial review of the distinctly legal question as to the reasonableness of a jury's verdict on given evidence, by application of a well-settled legal norm of reasonableness, ought to be abandoned and replaced by a Gallup poll of jurors, trial judge, and agreeing appellate justices on the one hand against disagreeing appellate justices on the other. Let rules of law be left to popular vote and let the judiciary abdicate its constitutional function! The reference to the twelve jurors being "on their oaths" was sly but gratuitous. Everybody concerned was under oath, the jurors, the trial judge, the five members of the Supreme Court of North Carolina, the nine members of the Supreme Court of the United States, and even the lawyers who argued the case in all the courts. Yet the philosophy of the law expressed by the dissenting bloc of four Justices was that twelve jurors, a trial judge and four members of the Supreme Court $=\mathrm{I}$; that five members of the Supreme Court of North Carolina and five members of the highest court in the land $=10$; ergo, that plaintiff should recover as upon a I7-to-Io plebiscite.

Indeed what has just been said in the preceding paragraph is overgenerous to Mr. Justice Black. He conveniently overlooked the fact that five eminent judges on the Supreme Court of North Carolina had held unanimously for the railroad and against the plaintiff. He made no mention of them in his Gallup poll. It is clear that the plebiscite which he had in mind was even more extravagant; i.e., I2 jurors + I trial judge +4 dissenters on the Supreme Court of the United States $=$ I7; five members constituting the majority of the highest court $=5$. Ergo, the plaintiff should recover as upon a $17-$-to-5 plebiscite.

That attitude was to be reflected time and again by the same four Justices in subsequent cases.

The dissenting opinion refused to agree that the "uniform federal rule" on directed verdicts announced by the Court correctly stated the law, but placed the dissent on a labored effort to show that the jury might reasonably have based its verdict on a finding that some undisclosed member of the crew other than Brady might have placed the derailer on the track and on a finding that an alleged defect in the rail opposite the derailer might have caused the casualty, regardless of the presence of the derailer on the track, although the track had been safely used for years and no such accident had ever happened except in this case where the derailer was placed and left on the track. The dissent is open advocacy of allowing a jury to award damages on no evidence but speculation.

In the above summarization of the law of negligence under the FELA as declared by the Court up to and including the Brady case, we have omitted any treatment of the doctrine of assumption of risk as a defense because Congress, by the amendment of $1939,{ }^{32}$ abolished assumption of risk as a defense and that doctrine

${ }^{39}$ Act of Aug. II, I939, 53 STAT. I404, 45 U. S. C. $\$ 54$ (I946). For example, the earlier case of Tiller v. Atlantic Coast Line R. R., 318 U. S. 54 (I943), cited and relied on by the Court's opinion in the Brady case, and decided on February $\mathrm{I}$, I943, turned entirely on assumption of risk and its abrogation as a defense by the amendment of 1939 . 
has since had no application in cases under the Act. Similarly we have not summarized the former law of contributory negligence as a defense, because contributory negligence was abolished as a defense and left only as a basis of a comparison of negligence between plaintiff and defendant in diminishment of damages, by the older amendment of $1908 .{ }^{33}$

In the Brady case the death occurred prior to the amendment of 1939 , but the case was tried subsequent to that amendment. The railroad, as an additional defense, pleaded Brady's assumption of the risk of his own injury under the law as it stood when he was killed. One of the grounds on which the Supreme Court granted certiorari was to consider whether the amendment of 1939 was retroactive, in its abolition of assumption of risk as a defense, as applied to a death which occurred before its enactment. Decision of that question was rendered unnecessary by the Court's holding that there was no sufficient evidence to go to the jury on the negligence issue. ${ }^{34}$

The Supreme Court has never passed on the question whether the amendment of 1939 was retroactive to eliminate assumption of risk as a defense in a case on a cause of action arising prior to the amendment. Of course, no such case could now arise.

\section{II}

By Its Decisions in fela Cases Since the Brady Case, the Supreme Court Has Progressively Undermined the Law of Negligence

As early as the October Term, I94I, a new trend of decisions had been indicated in Jacob v. New York City. ${ }^{35}$ That was just after President Roosevelt's seventh Democratic appointee to the Court, Mr. Justice Jackson, had been seated on October 6, 194.

The Jacob case did not arise under the FELA, but the decision had direct application to cases under that Act, because it arose under the Jones Act, ${ }^{36}$ applicable to seamen and which incorporated the FELA by reference. It indicated doubt as to the application of the well-settled "simple tool doctrine," which formerly applied to cases under the FELA. That doctrine was that as to simple tools, where the servant using them has at least as good an opportunity to observe and determine their condition as the master, there is no duty of inspection resting upon the master and no liability on his part for a defective condition.

Jacob, an experienced seaman, was injured when a worn wrench slipped off a nut by reason of the loose fit of the tool. There was testimony by him that he had called the attention of his foreman to the alleged defective condition of the wrench sometime before and had requested a new one.

The Court, in an opinion by Mr. Justice Murphy, in which Justices Frankfurter and Jackson concurred in the result but Chief Justice Stone and Justices Roberts

\footnotetext{
${ }^{33}$ Act of April 22, I908, 35 STAT. 66, 45 U. S. C. $\$ 53$ (1946).

${ }^{34}$ See 319 U. S. 777,320 U. S. 476,477 .

${ }^{35} 315$ U. S. 752, decided on March 30, 1942.

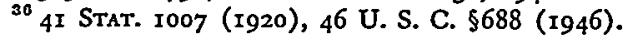


and Reed dissented, without expressly overruling the simple tool doctrine, cast considerable doubt upon its continued application to cases under the Jones Act and under the FELA, saying: ${ }^{37}$

The simple tool doctrine, used by the courts below to bolster their belief that the evidence was insufficient, does not affect our conclusion. In the first 'place, the contrariety of opinion as to the reasons for and the scope of the simple tool doctrine, and the uncertainty of its application, suggest that it should not apply to cases arising under legislation, such as the Jones Act, designed to enlarge in some measure the rights and remedies of injured employees. But even assuming its applicability, the doctrine does not justify withdrawing this case from the jury.

The Court went on to hold that even if the doctrine applied, the facts did not invoke the doctrine in view of the plaintiff's notice to the master that the simple tool was defective and his request for a new tool.

The dissenters obviously thought that the case should not have gone to the jury. The concurrence of Justices Frankfurter and Jackson in the result obviously indicated that they did not agree with the dictum that the simple tool doctrine might not be applicable at all under the Jones Act and under FELA. Those who joined fully in the opinion of Mr. Justice Murphy were only Justices Black, Reed, Douglas, and Byrnes. The dictum was ominous for the future development of the law of negligence.

\section{The 1942 Term}

An early case at the October Term, I942, Lilly v. Grand Trunk $R . R_{0}{ }^{38}$ in which the opinion was written by Mr. Justice Murphy and concurred in by the entire Court, except that Mr. Justice Frankfurter limited his concurrence to the result of the decision, continued the trend of broadening rules of liability in favor of the employee and against the employer and upset previous concepts as to liability under the Boiler Inspection Act. ${ }^{39}$

Unlike the FELA, the Boiler Inspection Act does not limit employer liability to cases of its negligence, but imposes an absolute and continuing duty to maintain the locomotive, and all parts and appurtenances thereof, in proper condition, and safe to operate ". . . without unnecessary peril to life and limb," and any violation of that absolute duty which proximately causes injury or death to an employee imposes absolute liability, in a suit brought under the FELA, regardless of nonnegligence of the employer. ${ }^{40}$ Obviously any unwarranted broadening of the coverage of the Boiler Inspection Act imposes a new and absolute liability against which there is no defense at all and which cannot be avoided by the highest degree of carefulness.

A long line of state and lower federal court cases had held that the requirements of the Boiler Inspection Act and of the corresponding Safety Appliance Acts ${ }^{41}$

${ }^{37} 315$ U. S. 752, 756-757 (footnote omitted). $\quad{ }^{38} 317$ U. S. 481 (I943).

3036 STAт. 9r3 (IgIr), as amended, 45 U. S. C. $\$ 22$ et seq. (1946).

${ }^{\circ}$ Lilly v. Grand Trunk R. R., 317 U. S. 48I, 485-486, and cases there cited.

${ }_{21} 7$ STAT. 53I (I893), as amended, 45 U. S. C. \$I et seq. (1946). 
covered only defects in construction or operation, within the employer's control, and not merely the presence of some dangerous object or foreign matter such as grease, coal, or ice from natural causes. ${ }^{42}$

In the Lilly case, petitioner slipped and fell, while he was pulling a waterspout, by reason of sliding on ice formed by natural causes. He alleged a true defect in a leak at the collar of the manhole from which water flowed onto the tender's surface and froze. The jury rendered a general verdict for petitioner, but by a special verdict found that there was no leak in or near the manhole. Obviously the general verdict was based on evidence only of the presence of ice and not of any mechanical defect. The appellate court of Illinois reversed a judgment on the verdict in favor of petitioner and against the railroad.

The Supreme Court reversed, holding that the absolute liability of the Act applied to the mere presence of ice on the tender, in effect overruling the whole line of cases cited in footnote 42 above, and broadening the coverage of the Act beyond any previously recognized concept.

We have heretofore brielly mentioned Tiller v. Atlantic Coast Line $R . R_{.}{ }^{43}$ as having preceded the Brady case at the October Term, 1942, and as being concerned only with the defense of assumption of risk as abolished by the amendment of 1939 to the FELA. However, it had much deeper implications flowing from the language used by Mr. Justice Black in his opinion for the Court, language which Mr. Justice Frankfurter sought properly to limit in his concurring opinion.

The 1939 amendment ${ }^{44}$ was carefully limited in its terms. It merely provided that, in any action brought under the FELA by an employee, he "shall not be held to have assumed the risks of his employment in any case where such injury or death resulted in whole or in part from the negligence of any of the officers, agents, or employees of such carrier..."

As Mr. Justice Frankfurter pointed out, this amendment clearly did not mean to abolish "assumption of risk" in the loose sense in which courts and lawyers had for centuries misused that term to mean that an employee always assumes the risk of natural and unavoidable hazards of his occupation, not caused by negligence of his employer, an excellent illustration, as Mr. Justice Frankfurter said, "of the extent to which uncritical use of words bedevils the law." The amendment only abolished assumption of risk in the other, technical sense, as a former common-law defense where the danger was caused by the negligence of the employer but was so apparent to the employee that courts held that the employee assumed the risk regardless of the employer's negligence. "The I939 amendment," as Mr. Justice

$\$ 2$ Ford v. New York, N. H. \& H. R. R., 54 F. $2 \mathrm{~d} 342$ (2d Cir. 193x) (grcase on a grab-iron); Reeves v. Chicago, St. P., M. \& O. Ry., I47 Minn. Ir4, I79 N. W. 689 (1920) (coal on a step); Slater v. Chicago, St. P., M. \& O. Ry., 146 Minn. 390,178 N. W. 813 (1920) (an ice bunker misplaced by a trespasser so as to project upon the running board); Chicago, R. I. \& P. Ry. v. Benson, 352 Ill. I95, I85 N. E. 244 (x933) (wire wrapped around a grab-iron); Harlan v. Wabash Ry., 335 Mo. 4r4, 73 S. W. 2d 749 (1934) (failure of employees to close a trap-door over a stoker); Riley v. Wabash Ry., 328 Mo. 910, 44 S. W. 2 I I36 (I93I) (clinker hook misplaced on a tender top by a fellow servant).

${ }^{3} 318$ U. S. 54, decided Feb. I, I943.

"Act of Aug. Ir, 1939, 53 STAT. 1404,45 U. S. C. $\$ 54$ (1946). 
Frankfurter said, ${ }^{45}$ "left intact the foundation of the carrier's liability-negligence" and only wrote out of the Act "'assumption of risk' as a defense where there is negligence" of the employer.

But Mr. Justice Black was not content with that clearly limited effect of the amendment in abolishing assumption of risk as a defense only where the carrier is negligent. He used broad enough language to imply that assumption of risk had also been abolished as a defense even where no negligence of the employer caused the risk but where it was a risk naturally inherent in the occupation.

Although his opinion gave a long, historical analysis of the development and use of the term in England and America and recognized the two inconsistent and ambiguous uses of the term pointed out by Mr. Justice Frankfurter, Mr. Justice Black said, ${ }^{46}$

We hold that every vestige of the doctrine of assumption of risk was obliterated from the law by the 1939 amendment, and that Congress, by abolishing the defense of assumption of risk in that statute, did not mean to leave open the identical defense for the master by changing its name to "non-negligence."

Of course the two defenses were not at all "identical." They were wholly different. The one which Congress abolished was the use of the term "assumption of risk" as a defense where the risk was caused by the negligence of the carrier. The other, the use of the term to refer to "non-negligence" of the carrier, the assumption of a natural and unavoidable risk of the occupation not caused by carrier negligence, plainly was not abolished by the amendment. The liability requirement of carrier negligence, as demonstrated by Mr. Justice Frankfurter, was specifically preserved by the very language of the amendment.

But Mr. Justice Black, by the language above quoted, obviously meant to hold that assumption of risk was "obliterated" in both senses, wholly contrary to the plain language of the statute itself. His attitude was further shown by his added statement: ${ }^{47}$

No case is to be withheld from a jury on any theory of assumption of risk; and questions of negligence should under proper charge from the court be submitted to the jury for their determination.

This was not only saying that the 1939 amendment had a meaning which Congress expressly did not intend, but it was further saying that every "question of negligence" must be submitted to the jury regardless of the evidence, a view repeated in his dissent in the Brady case, ${ }^{48}$ but squarely rejected by the Court in that case.

Thus the Tiller case was another dangerous precedent in the trend toward completely rewriting the law of negligence and leaving the carrier with no defense in any case, not even the one still left as the basis of the FELA, the non-negligence of the employer.

45 I8 U. S. at 68-72.

"Id. at 67 (italics supplied).
${ }^{48} I d$. at 58 .

${ }^{48} 320$ U. S. at 476 . 
And yet in another later case in the same volume, De Zon v. American President Lines, ${ }^{49} \mathrm{Mr}$. Justice Jackson, writing the opinion for the Court, concurred in by Chief Justice Stone and by Justices Roberts, Reed, and Frankfurter, made it perfectly clear that it was still the law of the Jones Act and of the FELA that negligence of the employer was the sole basis of liability and that where there was insufficient evidence of such negligence the case should not be submitted to the jury. Of course, Justices Black, Douglas, and Murphy dissented, vigorously asserting that a plaintiff has a constitutional right to have a jury pass on every suoh case and that no judicial review of the jury's determination should be permitted. Mr. Justice Rutledge did not participate in the consideration or decision but, if he had, it seems fairly certain that the bloc of four dissenters would have been solid.

Truly, at that point, as between the Tiller and De Zon cases, it was anybody's guess as to which way the Court would next jump on the fundamental proposition that the FELA does not impose liability without fault and that a case should not be submitted to the jury in the absence of sufficient evidence of negligence of the carrier proximately causing the injury or death to comply with the judicial standard of reasonableness.

The next case, Bailey $v$. Central Vermont $R y .{ }^{50}$ held with the administratrix of a deceased employee and against the railroad, in a very close case, reversing the Supreme Court of Vermont which had reversed judgment upon a verdict for plaintiff on the ground that there was no sufficient evidence of negligence of the railroad to warrant submission to the jury.

We need not here review the evidence. This writer cannot say that the holding was wrong, only that it was debatable. The decedent fell from a bridge, with no guard-rail, on which he was working in a customary way. The Court, in an opinion by Mr. Justice Douglas, held that there was "sufficient evidence to go to the jury on the question whether, as alleged in the complaint, respondent was negligent in failing to use reasonable care in furnishing Bailey with a safe place to do the work."51 This holding was very fairly stated.

Mr. Justice Douglas did not misstate the rule of law, as it is so often misstated, to imply that the law imposes an absolute duty to furnish a safe place to work or a duty to furnish an absolutely safe place to work. No such duty is imposed by the law. There can be no absolutely safe place to work on a railroad bridge. The duty is only "to use reasonable care in furnishing" a safe place to work, as Mr. Justice Douglas stated it. He also recognized that employer negligence is a prerequisite to liability and that there must be sufficient evidence of such negligence to warrant submission to the jury. Yet he used broad language to assert that "the jury is the tribunal under our legal system to decide that type of issue," citing the Tiller case, "as well as issues involving controverted evidence," citing other cases. Then he waxed even more emphatic, saying, "To withdraw such a question from the jury is to usurp its functions."

He further suggested that the method of trial by court and jury ${ }^{53}$

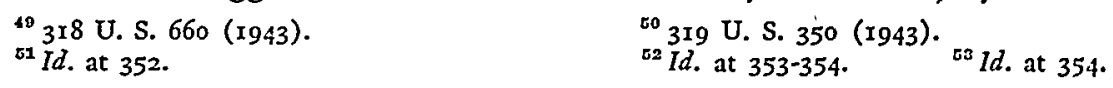


of determining the liability of the carriers and of placing on them the cost of these industrial accidents may be crude, archaic, and expensive as compared with the more modern systems of workmen's compensation. But however inefficient and backward it may be, it is the system which Congress has provided. To deprive these workers of the benefit of a jury trial in close or doubtful cases is to take away a goodly portion of the relief which Congress has afforded them.

This suggestion called forth from Mr. Justice Roberts, in his separate opinion, the following observation: ${ }^{54}$

Finally, I cannot concur in the intimation, which I think the opinion gives, that, as Congress has seen fit not to enact a workmen's compensation law, this court will strain the law of negligence to accord compensation where the employer is without fault. I yield to none in my belief in the wisdom and equity of workmen's compensation laws, but I do not conceive it to be within our judicial function to write the policy which underlies compensation laws into acts of Congress when Congress has not chosen that policy but, instead, has adopted the common law doctrine of negligence.

In Owens v. Union Pacific R. R., ${ }^{55}$ there was again presented the question whether the 1939 amendment, abolishing assumption of risk as a defense, applied retroactively to a cause of action arising prior to that amendment. Again the Court declined to pass on that question because it found that, if the amendment did not apply and if the old defense of assumption of risk did apply, on the evidence in the case the deceased employee had not, as matter of law, assumed the risk of a danger caused by negligence of his fellow servants. No opinion was expressed as to whether the evidence showed negligence on the employer's part, since the court below had not dealt with that question. It is implicit in the opinion of the Court by $\mathrm{Mr}$. Justice Rutledge, however, that sufficient evidence of negligence of the employer was essential before the case could be submitted to a jury. Mr. Justice Reed, joined by Chief Justice Stone and Mr. Justice Roberts, dissented on the ground that, in their view of the evidence, the defense of assumption of risk, as it stood prior to the amendment of 1939 , was good.

It will be observed that no railroad won a case at the October Term, I942. Every case was won by the plaintiff.

\section{The 1943 Term}

The first case at the October Term, I943, was Brady $v$. Southern $R y .{ }^{56}$ and it interrupted the current trend. The railroad won that case by a five-to-four decision, but it was the last case to be won by any railroad for five years. It has been fully reviewed. The majority opinion by $\mathrm{Mr}$. Justice Reed, carefully reviewed, restated, and reaffirmed the leading principles of the law of negligence under the FELA as they had been declared under the "old Court" and in long lines of decisions. The dissentient bloc of Justices Black, Douglas, Murphy, and Rutledge was solidified in opposition to taking any plaintiff's case from the jury.

\footnotetext{
"s $I d$. at 358.

${ }^{\circ 1} 319$ U. S. 715, decided June 14, 1943.

${ }^{50} 320$ U. S. 476 , decided Dec. 20 , 1943.
} 
Yet the very next month, on January I7, I944, the Court decided Tennant $v$. Peoria \& P. U. $R y .{ }^{57}$ opinion by Mr. Justice Murphy, separate concurrence by Justices Frankfurter and Jackson, dissent by Chief Justice Stone and Mr. Justice Roberts, which followed the Tiller and Bailey cases in holding for the plaintiff employee and, strangely enough, although it cited a number of older cases, made no reference to the Brady case of the preceding month, which was the latest decision under the Act.

The Tennant case seems clearly in conflict with the Brady case, although it did not purport to cast any doubt on the correctness of the Brady decision and did not even mention it. Indeed, the majority opinion, by Mr. Justice Murphy, specifically reaffirmed the fundamental principles: (r) that, in order to recover under the FELA, it is incumbent on the plaintiff to prove that the employer was negligent and that such negligence was the proximate cause in whole or in part of the fatal accident, citing the Tiller case; (2) that plaintiff is required to present probative facts from which both the negligence and the causal relation can reasonably be inferred; and (3) " "The essential requirement is that mere speculation be not allowed to do duty for probative facts, after making due allowance for all reasonably possible inferences favoring the party whose case is attacked." "58

That was a perfectly clear and correct statement of the controlling principles of law, entirely in line with the opinion and decision in the Brady case. Where the Tennant case departed from the Brady case, in the opinion of this writer, was that in the Tennant case the Court did not correctly apply the very principles of law it there enounced, but authorized a jury finding of proximate causation by allowing pure speculation "to do duty for probative facts." To demonstrate this error it is necessary to review the facts.

The intestate, Tennant, was an experienced switchman in switching yards in which he had worked for several years and with which he was perfectly familiar. On the night in question his crew was engaged in one of its nightly tasks of coupling freight cars and removing them from a track. A Diesel-electric engine was brought down onto the track from the north, and its front, or pilot, end was headed south. There were about twenty cars in various groups on this track. They were to be coupled together and moved northward out of this track to other locations. In the course of these coupling operations, the engine stopped and started six or eight times, gradually moving southward.

After all the twenty cars had been coupled, the engine remained stationary for five or ten minutes before the engineer received the back-up signal from the foreman. While waiting for the back-up signal, the engineer saw Tennant on the west side of the engine placing his raincoat in a clothes compartment beneath the cab window. After putting on a cap and jacket he walked around the north, or rear, end of the engine, and was never seen alive after that. There were no eye witnesses

57321 U. S. 29 (1944).

${ }^{58}$ Citing and quoting from Galloway v. United States, 319 U. S. 372, 395 (1943) and citing with approval Atchison, T. \& S. F. Ry. v. Toops, $28 \mathrm{I}$ U. S. 35I (1930). 
as to what happened to Tennant and no direct evidence as to his precise location at the moment he was killed. It was his duty to stay ahead of the engine as it moved back out of the track, protect it from other train movements, and attend to the switches.

When the engineer received the back-up signal from the foreman, he obeyed and pulled the twenty cars out of the track. The fact that Tennant was missing was first noticed when the engine reached a point some distance north of the switch. An investigation revealed blood marks on the track in question, about seven or eight car lengths south of the switch. There was a pool of blood a foot and a half north of those marks. Nearby, between the rails, were Tennant's right hand, his cap, and his lighted lantern. His torso was found at the switch, while his head was discovered about fourteen car lengths north and west of the switch.

An examination of the engine and cars disclosed only a tiny bit of flesh on the outside rim of the north wheel of the third car from the engine. There was no evidence of his having slipped or fallen from any part of the engine or cars or of his having been struck by the engine itself. The evidence clearly indicated that he was first struck by the third car from the engine.

The case was submitted to the jury on the allegation that Tennant's death resulted from the railroad's negligence, in that the engineer backed the engine and cars northward out of the track without first ringing the engine bell, which was alleged to be in violation of a company rule. There was conflicting evidence as to whether the rule was for the benefit of crew members who were aware of switching operations and as to whether it was customary for the bell to be rung under such circumstances. The rule in question itself specifically provided: "The unnecessary use of either the whistle or the bell is prohibited."

In the present writer's view, even if the jury was justified in finding a violation of the rule in the failure to ring the bell, as constituting negligence, still there was an utter absence of evidence sufficient to sustain a jury finding that such negligence was in any way the proximate cause of the death of Tennant. How he came to his death can only be the subject of speculation and conjecture. One man's guess is as good as another's.

The gruesome details as to his blood and dismembered remains, while they naturally tend to exert a "hydraulic pressure" of sympathy on any mind considering those details, logically had no tendency to prove how Tennant was killed. They only proved that he was killed by being run over, but how and where he came in contact with the train of cars, or how he came to be under the moving wheels, was left entirely to guess or speculation.

True, one crucial fact which was outstanding in the Brady case was absent from the Tennant case. Brady knew all the surrounding conditions and he himself gave the signal for the fatal movement. Tennant, while he apparently knew all the surrounding conditions, did not give the signal for the fatal movement. It was given by his foreman. Perhaps this is the factual difference which controlled the 
difference in decision in the two cases. However, it is hard for this writer to see in the Tennant case any proof that the alleged negligent failure to ring the bell was the proximate cause of Tennant's death. He may have stumbled and fallen between the cars. He may have fallen off a car. He may have been walking ahead of the engine and been struck by it. Or he might even have been the victim of a heart attack. The causative element simply was not made to appear in the evidence.

It seems to this writer that Mr. Justice Murphy's opinion completely overlooked the fact that the burden of proof was on the plaintiff, and not on the defendant. It indulged a presumption that Tennant was not negligent, and, upon that presumption, erected another presumption, not supported by proof, that the railroad's negligence was the proximate cause of his death.

It will be observed that the Brady case was the only case won by a railroad, and that by a bare five-to-four decision, and that the other case, Tennant, at the 1943 Term, was decided against the railroad and in favor of the plaintiff, on purely speculative evidence, and that the Court did not even cite the most recent Brady case in the Tennant opinion.

\section{The 1944 Term}

At the I944 Term, the Tiller case came back to the Supreme Court a second time $^{59}$ and again was lost by the railroad, Mr. Justice Black writing the opinion for the Court and Chief Justice Stone and Justice Roberts dissenting.

Following the previous decision by the Supreme Court in that case ${ }^{\mathbf{0} 0}$ the plaintiff sought to "mend her licks" by amending her complaint in the district court, over the railroad's objection, by charging that, in addition to railroad negligence previously alleged, the decedent's death was caused by the railroad's violation of the Boiler Inspection $\mathrm{Act}^{61}$ and the Rules and Regulations prescribed by the Interstate Commerce Commission pursuant to the provisions of that Act. Thus, in case she should fail to get a jury verdict on the issue of railroad negligence, she sought to clinch her recovery by invoking the theory of the Boiler Inspection Act of absolute liability regardless of non-negligence of the railroad. The jury returned a verdict in favor of the plaintiff, the district court refused to set it aside, but the Court of Appeals for the Fourth Circuit reversed. ${ }^{62}$ The Supreme Court again granted certiorari on the plaintiff's petition.

The Court of Appeals, since the evidence on the issue as to railroad negligence at the second trial was substantially the same as at the first trial, bowed to the first decision of the Supreme Court (3I8 U. S. 54), that the evidence on that issue was sufficient to go to the jury. But, since plaintiff had amended her complaint to specify a new element of liability under the Boiler Inspection Act and Rules as an alternative ground for recovery, and since the verdict was a general one and hence did not disclose whether it was based on the old negligence issue or on the new Boiler

\footnotetext{
${ }^{59}$ Tiller v. Atlantic Coast Line R. R., 323 U. S. 754, decided Jan. I5, 1945.

${ }^{60}$ Tiller v. Atlantic Coast Line R. R., 318 U. S. 54 (1943).

${ }^{\text {e1 }} 36$ STAT. 913 (IgIr), as amended, 45 U. S. C. $\$ 22 \mathrm{et} \mathrm{seq.} \mathrm{(1946).}$

62 Atlantic Coast Line R. R. v. Tiller, I42 F. 2d 718 (4th Cir. 1944).
} 
Inspection Act issue, the Court of Appeals dealt with the latter issue as uncontrolled by the previous decision by the Supreme Court, and held that there was no evidence that the alleged violation of the Boiler Inspection Act was "the proximate cause of the accident in whole or in part."

The alleged violation of the Boiler Inspection Act and of the Commission's rules pursuant thereto was a failure to have the locomotive in yard service between sunset and sunrise equipped with

two lights, one located on the front of the locomotive and one on the rear, each of which shall enable a person in the cab of the locomotive under the conditions . . . to see a dark object ... f for a distance of at least 300 feet ahead and in front of such headlight. . . .

The locomotive, which pushed backwards the string of cars one of which struck and killed the decedent Tiller, was operated in yard service between sunset and sunrise, had such a headlight as required properly burning on its front end, but did not have such a light burning on its rear end. If such a light had been burning on the rear end, its illumination would have been cut off by the cars attached to that end and could not have disclosed to the persons in the cab the "dark object," Tiller, for a distance of 300 feet. The Court of Appeals so held and hence held that, even if the light rule was violated, that violation could not have been the proximate cause of 'Tiller's death since, obviously, even if the rear-end light had been burning it could not have disclosed to the locomotive crew the presence of Tiller in the path of the moving cars, since the cars themselves would have cut off the illumination of that light. In this writer's view, that was obviously a sound holding.

Mr. Justice Black, for the Supreme Court, assumed without deciding that the railroad could, consistently with the rule, so obscure the rear-end light, ${ }^{63}$ but he held that the jury had the right to find (speculate, I think; nothing in the evidence proved it) that ${ }^{64}$

the diffused rays of a strong headlight even though directly obscured from the front, might easily have spread themselves so that one standing within three car lengths of the approaching locomotive would have been given warning of its presence, or at least so the jury might have found.

It will at once be observed that this holding was a distinct perversion of the very terms of the rule relied upon. The rule did not require a light sufficient to give one standing in the path of the locomotive and cars a warning of their presence or approach. It only required a light sufficient to give a warning to "a person in the cab" of the presence of "a dark object" within 300 yards. The warning contemplated by the rule was to be given to the locomotive crew, not to the "dark object" in the path of the movement.

\footnotetext{
${ }^{03}$ Nothing in the rule denied to the railroad the right to obscure such a light with cars artached to a yard engine. The practice was general railroad practice. Indeed the only function of a yard engine, even between sunset and sunrise, is to handle cars at one or the other of its ends. It has no function to operate merely in "splendid isolation."

${ }^{04} 323$ U. S. at 578-579 (italics supplied).
} 
On the facts it would have been simply ridiculous for the jury to have found that if the light had been burning it would, through the intervening obstruction of the cars, have illuminated Tiller so as to have warned the locomotive crew of his presence in the path of the movement, which was the sole requirement of the rule. The opinion by Mr. Justice Black did not even suggest that the jury verdict could have lawfully been based on that theory. Instead, the opinion in terms held that the jury could competently have found that rays of the light, if burning, and in spite of the complete obstruction of the intervening cars, "might easily have spread themselves" so as to warn Tiller of the approaching locomotive, which was neither the purpose nor the effect of the rule relied on. And even as to that theory, not within the rule at all, the opinion authorized a jury verdict to be based on mere guess or speculation.

The holding was obviously contrary to the holding in the Brady case, yet that recent case was not referred to in the opinion. As stated, Chief Justice Stone and Mr. Justice Roberts dissented.

The trend against railroads and in favor of employees was quickly continued in Blair v. Baltimore \& $O . R . R .{ }^{65}$ decided the same month, January 29 , 1945, in which again Mr. Justice Black wrote the opinion for the Court and Chief Justice Stone and Mr. Justice Roberts dissented. Again the majority of seven Justices, all appointed by President Roosevelt, did not "think like" Chief Justice Stone, to use the President's own phrase.

That case also arose prior to the amendment of 1939, which abolished assumption of risk as a defense. Again the Court refused to pass upon the question whether that amendment applied retroactively to a cause of action which arose prior to its enactment, because it held that, even if the old defense of assumption of risk was available in the case, on the evidence the employee had not, as matter of law, assumed the risk of his own injury.

In unloading a car standing at a platform, it was Blair's duty to move three ro-inch seamless steel tubes, approximately 30 feet long and which were greased and slick. He went to his superior, informed him that the pipes were too heavy for him to move, and suggested that it was not customary for the railroad to unload pipes of this kind at its warehouse, but to send the car directly to the consignee's place of business where it had proper equipment for unloading heavy material. The suggestion was rejected and Blair was told to get two other men to help him. He insisted that three men could not unload the heavy pipes, but that suggestion was overridden and he was told to go ahead and do the work or they "would get somebody else that would." $\mathrm{He}$ and the other two men then undertook to do the work with the best available equipment, a "nose truck." One pipe was moved successfully. The second pipe slipped, while they were undertaking to handle it in the same manner, causing the truck to kick back, injuring Blair.

There was indication in the evidence, said Mr. Justice Black, that the immediate ${ }^{\circ 0} 323$ U. S. 600 (1945). 
cause of the greasy pipe's slipping as it did was either (I) an uneven place on the warehouse floor due to its having sunken in; or (2) pushing the nose truck against the standing company truck with such force as to make the tube move with great suddenness (obviously wholly inconsistent theories as to causation). It was further suggested in support of recovery that the fact that the other two men released their grip after the pipe began to slip also contributed to the suddenness and force of the kickback of the nose truck.

The Pennsylvania Supreme Court reversed verdict and judgment for Blair, holding that he had assumed the risk of his injury by remaining in employment and that there was no evidence to support a finding of railroad negligence in any respect. $^{\text {Bb }}$ The Supreme Court of the United States reversed that holding by a seven-to-two decision. We do not argue here the merits of that decision, although that it was highly debatable is shown by the fact that Chief Justice Stone and Mr. Justice Roberts dissented. As to assumption of risk, it is not important for the future, in view of the amendment of 1939 abolishing the defense of assumption of risk in any case in which negligence of the employer proximately causes the injury in whole or in part. The case is significant of the trend of decisions on negligence issues in the following expressions in Mr. Justice Black's opinion for the Court: ${ }^{\text {B }}$

To deprive railroad "workers of the benefit of a jury trial in close or doubtful cases is to take away a goodly portion of the relief which Congress has afforded them." Bailey v. Central Vermont R. Co., 319 U. S. 350 , 354 . and ${ }^{\text {Bs }}$

We think there was sufficient evidence to submit to the jury the question of negligence posed by the complaint. The duty of the employer "becomes 'more imperative' as the risk increases." Bailey v. Central Vermont R. Co., $3^{\text {rg }}$ U. S. $350,352,353$. See also Tiller v. Atlantic Coast Line, 318 U. S. 54, 67. The negligence of the employer may be determined by viewing its conduct as a whole. Union Pacific R. Co. v. Hadley, 246 U. S. 330, 332, 333. And especially is this true in a case such as this, where the several elements from which negligence might be inferred are so closely interwoven as to form a single pattern, and where each imparts character to the others.

The first of the above quotations is pure petitio principis, completely begs the very question before the Court. If the evidence was not sufficient to meet the judicial test for submission to the jury on the negligence issue, then to take the case from the jury would not take away "a goodly portion" or any portion of the relief which Congress had afforded railroad workers, because Congress had afforded them no remedy at all except for injuries caused by employer negligence. This statement of the opinion, quoted from the Bailey case, is singularly unhelpful to lawyers, litigants, or to lower court judges. The second statement, with its mixed metaphor of closely interwoven elements forming a single pattern, each element

or 349 Pa. 436, 37 A. 2d 736 (1944).

${ }^{\circ 7} 323$ U. S. 600,602 .

${ }^{\circ}{ }^{3}$ d. at 604 . 
imparting character to the others, is equally unhelpful. Both indicate merely a growing determination, following the Tiller and Bailey cases, to let all cases go to the jury. It is again significant that the opinion does not mention the recent Brady case.

In Herb v. Pitcairn, ${ }^{69}$ the Court split wide open on what seems to have been a very simple and plain matter. In two cases under the FELA there dealt with, the majority of the Court, in an opinion by Mr. Justice Jackson, concurred in by Chief Justice Stone and Justices Roberts, Reed, and Frankfurter, held that since the records were ambiguous as to whether the state court judgments of dismissal rested on a federal ground or on an adequate state ground, the causes would be continued for such period as would enable counsel for petitioners with all convenient speed to apply to the state court for amendment, or certificate, showing whether it intended to rest its judgments on the state ground or the federal ground.

The case did not involve any principle of the law of negligence and, hence, is outside the scope of this paper. It involved a question of jurisdiction of a state court under the law of Illinois. It also involved a federal question, whether the action was barred under the FELA. Mr. Justice Jackson, for the Court, properly held that from the time of its foundation the Supreme Court had adhered to the principle that it would not review judgments of state courts that rest on adequate and independent state grounds. Since the state court, in this case, had left it ambiguous whether its judgment rested on the state ground or the federal ground, the Supreme Court, instead of dismissing the case because the federal ground did not clearly appear, held the case pending application to the state court for clarification or amendment, an eminently sensible thing to do.

Obviously motivated by a strong feeling that the plaintiffs had been subjected to the law's delays and that their path to verdict and recovery against the railroad ought to be speeded, Mr. Justice Black filed a vigorous dissent, joined in by Justices Douglas and Murphy. He seemed to think that the state court ground was trivial, even non-existent, that the federal ground clearly appeared, and that it ought to be decided at once, so as to speed the plaintiffs to recovery.

Mr. Justice Rutledge filed a separate dissent, taking the position that the state court judgment was clearly based on decision of the federal question and that that decision was wrong and ought to be reversed without further delay.

The bloc of four dissenters was solid in favor of the plaintiffs.

The case came back to the Supreme Court in Herb v. Pitcairn, ${ }^{70}$ on a certificate from the Supreme Court of Illinois making it clear that its decision had rested on the federal ground of the bar of the statute. Mr. Justice Jackson, writing for the unanimous Court, held that that question had been wrongly decided and reversed the judgment of the state court. The perfervid dissents in the first decision thus appear to have been "much ado about nothing," except to show the fixed penchant of the four dissenters in favor of plaintiffs under the FELA.

It will again be seen that no case was won by a railroad at the October Term, 1944, unless the brief delay in first Herb v. Pitcairn be considered a Pyrrhic victory.

${ }^{69} 324$ U. S. II7, decided Feb. 5, r945.

${ }^{70} 325$ U. S. 77, decided April 23, r945. 
The I945 Term

Poff v. Pennsylvania R. R., ${ }^{71}$ continued the trend of decisions in favor of plaintiffs and against railroad defendants. Here, again, the case did not involve any question of negligence law. Negligence was conceded. The sole question was whether a cousin of the deceased employee, who was dependent, had a right to recover as beneficiary under the statute, when two sisters and a nephew survived, nearer of kin to the decedent than the cousin but not dependent.

The FELA provided that the carrier's liability in case of the death of an employee, caused by carrier negligence, runs:

to his or her personal representative, for the benefit of the surviving widow or husband and children of such employee; and, if none, then of such employee's parents; and, if none, then of the next of kin dependent upon such employee...

This deceased employee left no widow, no child, and no parent surviving. His surviving next of kin were two sisters and a nephew, not dependent and hence not beneficiaries for whom recovery could be had under the statute. The remoter surviving kinsman, the cousin, while dependent, was not the "next of kin" and hence clearly was not a proper beneficiary under the statute and under the clear rule of many cases. ${ }^{72}$

Yet Mr. Justice Douglas, writing for the majority of the Court, stretched the statutory grant of beneficiary right so as to cover the dependent cousin who plainly was not "next of kin." And this was done, forsooth, because otherwise "the nearer next of kin who are not dependent are [would be] treated as a preferred class not for the purpose of allowing them to recover but to defeat a recovery by all next of kin" (p. 402). Yet this is just what the Act of Congress plainly intended, and the majority "drove a coach and four" through the Act in order to make a beneficiary one whom Congress, by apt language, had intended to exclude.

Mr. Justice Douglas was joined in this decision by Chief Justice Stone and by Justices Black, Reed, Murphy, and Rutledge.

Mr. Justice Jackson, absent at Nuremberg, took no part. Mr. Justice Frankfurter, joined by Mr. Justice Burton, dissented on the ground that Congress plainly did not intend to make a remote dependent who was not "next of kin" a beneficiary under the Act.

Not only had the Supreme Court in the recent series of decisions, to use Mr. Justice Roberts' phrase, stretched the law of negligence so as virtually to make of a negligence statute a workmen's compensation statute. In this case it went further and created, by judicial legislation, a whole new class of beneficiaries whom Congress had not made beneficiaries under the Act.

In Lavender v. Kurn, ${ }^{73}$ the Court reached the ultima Thule for authorizing a recovery on purely speculative evidence, in an opinion by Mr. Justice Murphy, joined

${ }^{71} 327$ U. S. 399, decided Feb. $25,1946$.

73 Michigan Central R. R. v. Vreeland, 227 U. S. 59, 68 (1913); Gulf, C. \& S. F. Ry. v. McGinnis, 228 U. S. 173, I75 (1913); Garrett v. Louisville \& N. R. R., 235 U. S. 308, 313 (I914).

${ }^{73} 327$ U. S. 645, decided March 25, 1946. 
in by Justices Black, Douglas, Rutledge, and Burton. Chief Justice Stone and Mr. Justice Frankfurter concurred only in the result, not in the majority opinion. Mr. Justice Reed dissented. Mr. Justice Jackson, absent at Nuremberg, took no part.

To make clear the extraordinary nature of the holding and its complete departure from settled precedents, it is necessary to review the facts. The decedent, Haney, was a switchtender near Grand Central Station in Memphis and his duties included the throwing of switches for the Illinois Central, the Frisco, and other railroads using that station. On a dark evening, about 7:30, a west-bound interstate Frisco passenger train stopped on the Frisco main line, its rear some 20 or 30 feet west of a switch in the charge of Haney. In performance of his duties, Haney threw or opened the switch on the north side of the track to permit the train to back into the station.

The railroad claimed that Haney was then required to cross to the south side of the track before the train passed the switch. The conductor of the train testified that he saw Haney so cross. There was evidence also that Haney's duties required him to wait at the switch north of the track until the train had cleared, close the switch, return to his shanty near the crossing, and change the signals from red to green to permit trains on the Illinois Central tracks to use the crossing. The Frisco train cleared the switch, backing at the rate of 8 or Io miles per hour. But the switch remained open and the signals still were red. Upon investigation Haney was found north of the track near the switch, face down on the ground, unconscious. An ambulance was called, but he was dead upon arrival at the hospital.

Haney had been struck in the back of the head, causing a fractured skull from which he died. There were no eye-witnesses to the fatal blow and nobody can know what hit him. Apparently he had fallen toward the south, with his head to the south, but his head was about $5 \frac{1}{2}$ feet north of the Frisco track, plainly out of reach of the train. There were marks indicating that his toes had dragged a few inches southward as he fell, plainly showing that the impulse of whatever blow struck him in the head had projected him toward the track and the train, instead of away from the track and the train, as would have been the case if the blow had been dealt by the train or some part of the train or an attachment to it. Yet, whatever struck him did not bring him close enough to the train to put him in contact with it.

The injury to Haney's head was evidenced by a gash about two inches long, from which the blood flowed. The back of his cap had a corresponding black mark about an inch and a half long and an inch wide, running at an angle downward to the right of the center of the back of the head. A spot of blood was later found at a point three or four feet north of the tracks, again beyond the reach of the moving train. The conclusion of an autopsy was that his skull was fractured by "some fast moving small round object." One of the examining doctors testified that such an object might have been attached to a train backing at the rate of 8 or ro miles per hour, but he also admitted that the fracture might have resulted from 
a blow from a pipe, or a club, or some similar round object in the hands of an individual.

The plaintiff's theory was that Haney was struck by the curled end or tip of a mail hook hanging down loosely on the outside of the mail car of the backing train. This curled end was 73 inches above the top of the rail, which was 7 inches high; that is, it was 80 inches, or 6 feet 8 inches, above the ground. There was no evidence that Haney was a man of 6 feet 8 inches or more in height so as to be able to be struck by this curled end of the mail hook. He was $671 / 2$ inches, or 5 feet $7 \frac{1}{2}$ inches, tall.

In an attempt to make it appear that the mail hook might have struck him in the back of the head, plaintiff introduced evidence that both east and west of the switch there was an uneven mound of cinders and dirt rising at its highest points I8 to 24 inches above the top of the rail. Witnesses differed as to how close the mound approached the rail, the estimates varying from 3 to 15 feet. If the mound had been I2 inches high at a point about a foot from the side of the mail car, and if Haney had been standing on the mound at this point, and all of this was pure speculation, he possibly could have been hit by the end of the mail hook, the exact point of contact depending upon the height of the mound at the particular point-if, in fact, he was standing on the mound at that point, of which there was no evidence.

The railroad's theory was that Haney had been murdered. It pointed to the estimates that the mound was Io to $x_{5}$ feet north of the rail, making it impossible for the mail hook end to reach a point of contact with Haney's head. Photographs in evidence showed that the ground was level north of the rail for at least Io feet. It appeared in the evidence that many hoboes and tramps frequented the area at night in order to get rides on freight trains, by reason of which Haney carried a pistol to protect himself. The pistol was found loose under his body by those who came to his rescue. It was testified, however, that the pistol had apparently slipped out of his pocket or scabbard as he fell. His clothes were not disarranged, and there was no evidence of a struggle or fight. No rods, pipes or weapons of any kind, except Haney's own pistol, were found near the scene. His gold watch and diamond ring were still on him after he was struck. Six days later his unsoiled billfold was found on a high board fence about a block from the place where Haney was struck and near the point where he had been placed in the ambulance. It obviously could not have been knocked to that point by the force of the blow which killed him. It contained his social security card and other effects, but no money.

A verdict for $\$ 30,000$ for the plaintiff was rendered by the jury, and judgment thereon was entered for the plaintiff by the trial court. On the above state of facts, the Supreme Court of Missouri, in Lavender v. Kurn, reversed, saying very properly: ${ }^{74}$

A court should never withdraw a question from the jury unless all reasonable men

74 354 Mo. 196,208 , I89 S. W. 2d 253, 258-259 (1945). 
in the honest exercise of a fair and impartial judgment would draw the same conclusion from the facts which condition the issue. Courtney v. Ocean Accident \& Guaranty Corporation, 346 Mo. $703,142 \mathrm{~S}$. W. $2 \mathrm{~d} 858$, but it is well settled that verdicts may not be based on conjecture and speculation. Hamilton v. St. Louis-San Francisco Ry. Co., 318 Mo. x23, 300 S. W. 787; Mullen v. Lowden et al., 344 Mo. 40, 124 S. W. 2d II52; Lappin v. Prebe et al., 345 Mo. 68, ז3 I S. W. 2d 51 I; Federal Cold Storage Co. v. Pupillo, 346 Mo. I36, I39 S. W. 2 d 996, loc. cit. Ioor, and cases there cited. Also, it is well settled that a mere possibility of negligence is not a sufficient foundation for an inference of negligence which will justify submission of a case to a jury. Mullen v. Lowden et al., supra, I24 S. W. 2d loc. cit. II56.

With the hearsay eliminated, we think that all reasonable minds would agree that it would be mere speculation and conjecture to say that Haney was struck by the mail hook, and we are constrained to rule that plaintiff failed to make a submissible case on that question. And we also rule that there was no substantial evidence that the uneven ground and insufficient light were causes or contributing causes of the death of Haney.

This was a perfectly sound decision and entirely in line with the law as announced by the Supreme Court of the United States in Brady v. Southern Ry. (320 U. S. 476 ), in which, as we have seen, the Court had recently held, at the October, I943, term, that the evidence of an employer's negligence under the FELA must be more than a scintilla before the case can be properly left to the trier of the facts; that evidence sufficient to raise only a mere speculation or conjecture as to negligence of the defendant, or that such negligence was the proximate cause of injury or death, is not sufficient to support a verdict for the plaintiff; and that "Bare possibility is not sufficient."

However, on that state of facts, Mr. Justice Murphy, writing for the Supreme Court of the United States, in terms used the very language of speculation to reason that Haney might possibly have been struck by the mail hook. He again completely overlooked the fact that the burden was on the plaintiff to prove negligence and proximate cause. He speculated that the high point of the mound might have been close enough to the track for a man standing on it to have been struck by the mail hook. He speculated, in terms, that Haney might have been standing on such high point of the mound in such proximity to the track. He said that from the above evidence the jury might reasonably have inferred that the end of the mail hook struck Haney in the back of the head, in spite of the fact that Haney fell forward toward the track, instead of alongside or away from the track. He even speculated that Haney might well have been struck and "then wandered in a daze to the point where he fell forward." He authorized this form of pure speculation by the jury because of the difficulty of the facts (which he admitted), that "there is evidence tending to show that it was physically and mathematically impossible for the hook to strike Haney" and that there were "facts from which it might reasonably be inferred that Haney was murdered."

In spite of this Mr. Justice Murphy said: ${ }^{75}$

${ }^{75} 327$ U. S. at $652-653$. 
But such evidence has become irrelevant upon appeal, there being a reasonable basis in the record for inferring that the hook struck Haney. The jury having made that inference, the respondents were not free to relitigate the factual dispute in a reviewing court. Under these circumstances it would be an undue invasion of the jury's historic function for an appellate court to weigh the conflicting evidence, judge the credibility of witnesses and arrive at a conclusion opposite from the one reached by the jury. See Tiller v. Atlantic Coast Line R. Co., 3 I8 U. S. 54, 67-68; Bailey v. Central Vermont $R$. Co., 3 rg U. S. 350, 353-354; Tennant v. Peoria \& P. U. R. Co., 32I U. S. 29, 35. See also Moore, "Recent Trends in Judicial Interpretation in Railroad Cases Under the Federal Employers' Liability Act," 29 Marquette L. Rev. 73.

This amazing statement, on its face, shows that Mr. Justice Murphy and the majority of the Supreme Court completely overlooked the burden of proof which rested on the plaintiff. It was not necessary, as the above quotation clearly implies it was, that a reviewing court "arrive at a conclusion opposite from the one reached by the jury." It was not necessary for a reviewing court to adopt the defendant's theory that Haney had been murdered. The burden was on the plaintiff to prove negligence and proximate cause. All that a reviewing court needed to do-and that the Supreme Court of Missouri did very precisely-was to find that plaintiff had not made out a case sufficient to go to the jury in support of his theory of the case, that his theory was based on pure speculation and conjecture and on not more than a scintilla of evidence.

Evidently Mr. Justice Murphy had at least some subconscious realization of the inconsistency of his above holding, for he undertook to answer the contention that the jury's verdict was based purely upon speculation and conjecture, saying: $7^{76}$

It is no answer to say that the jury's verdict involved speculation and conjecture. Whenever facts are in dispute or the evidence is such that fair-minded men may draw different inferences, a measure of speculation and conjecture is required on the part of those whose duty it is to settle the dispute by choosing what seems to them to be the most reasonable inference. Only when there is a complete absence of probative facts to support the conclusion reached does a reversible error appear. But where, as here, there is an evidentiary basis for the jury's verdict, the jury is free to discard or disbelieve whatever facts are inconsistent with its conclusion. And the appellate court's function is exhausted when that evidentiary basis becomes apparent, it being immaterial that the court might draw a contrary inference or feel that another conclusion is more reasonable.

This opinion marked the low point in the long series of departures by the Supreme Court of the United States from the well-settled law of negligence. In express terms Mr. Justice Murphy himself speculated on the evidence. In express terms he held that the jury was authorized to speculate. This decision was squarely in conflict with the Brady case, and, yet, again, the opinion of the Court did not see fit even to refer to the Brady case.

As stated above, Chief Justice Stone and Mr. Justice Frankfurter did not concur in the opinion but only in the result. Mr. Justice Reed dissented. One of the soundest judges on the court, Mr. Justice Jackson, was still absent in Nuremberg and took no part in the consideration or the decision of the case.

\footnotetext{
${ }^{78} I d$. at 653 .
} 
It will again be seen that the two decisions at the 1945 term were in favor of plaintiffs and against the railroads, and both of them widely departed from settled precedents in the law.

The Reaction of Lower Federal Courts, State Courts and the Bar to the Trend of Supreme Court Decisions

At this point, following the Lavender case, decided March 25, 1946, the lower federal courts, the state courts, and the bar of the country were all left in a complete quandary as to what had become of the well-settled principles of the law of negligence. In particular, the lower federal and state courts were in a helpless condition as to how to deal with FELA cases before them. If they applied the principles carefully reviewed and restated in the Brady case, and took a case from a jury, or reversed a jury verdict and trial court judgment, on the ground that, by all previously recognized judicial standards, plaintiff's evidence was insufficient to raise more than a speculation, guess or conjecture as to railroad negligence or proximate causation, they could only read the Supreme Court decisions since Brady as clearly indicating that they would be reversed if the case got to the Supreme Court.

On the other hand, if they let every speculative and conjectural theory of a plaintiff, on such non-probative evidence as that involved in the Lavender case, go to the jury and allowed a verdict for plaintiff to stand, they conscientiously felt that they were abdicating their judicial function. They could only read the recent cases, since Brady and through Lavender, as expressing a determination by the Supreme Court, led by Justices Black, Douglas, Murphy, and Rutledge, to abandon negligence and proximate cause as the prerequisites to liability under the FELA and to apply that Act as a workmen's compensation law, imposing liability without fault, and yet violating the whole basis of workmen's compensation laws by not fixing a definite schedule of limited compensation awards but still leaving "the sky the limit" for the generosity of juries with other people's money. ${ }^{77}$

This is no place to review the many expressions by other courts of the feeling of dismay and futility in which they were left by the Supreme Court decisions since the 1942 term. It is sufficient to give one dramatic example, so striking, and from such a source, ${ }^{78}$ that it was not long in forcing itself upon the attention of the Supreme Court. ${ }^{79}$

In Griswold v. Gardner, ${ }^{80}$ decided May 15,1946 , less than two months after the Supreme Court decision in the Lavender case, the Court of Appeals for the Seventh Circuit had before it an appeal in a case involving the death of a brakeman. The evidence was strikingly similar to that in the Lavender case, in that there was no showing as to how the deceased was killed and contentions as to railroad

\footnotetext{
${ }^{77}$ In an old case, Cashion v. Telegraph Co., ${ }^{123}$ N. C. $267,273,3 \times$ S. E. 493,494 (1898), the Supreme Court of North Carolina, in an opinion by Judge Douglas, had used a noteworthy expression: ". . . generosity is not a virtue when dealing with the property of others." Today courts seem only too glad to forget that earlier morality.

${ }_{78}$ Griswold v. Gardner, 155 F. 2d 333 (7th Cir. 1946).

${ }^{79}$ Wilkerson v. McCarthy, 336 U. S. $53,6 x-62$ (1949).

${ }^{80}$ I55 F. 2d 333 (7th Cir. 1946).
} 
negligence and proximate causation were left to inference based on pure speculation and conjecture. Verdict and judgment had been rendered for plaintiff in the district court and the principal question on appeal was whether the evidence was sufficient for submission to the jury and to support the verdict and judgment based on a finding that the railroad's negligence proximately caused the death.

It is obvious that the majority of the Court of Appeals felt that the evidence was insufficient to raise more than a speculation or conjecture and that the verdict and judgment were unwarranted. However, they wrung their hands in helplessness, in view of the recent Supreme Court opinions, and affirmed the district court, against their own judicial judgment, under the impulsion of the Supreme Court decisions plainly authorizing and even encouraging speculation by juries in these cases. The opinion for the court, by Circuit Judge Major, so plainly reflected the feeling of futility in which lower federal courts were left by the line of cases ending with Lavender and so accurately summarized the effect on the law of negligence of those cases, that we quote from it in extenso as follows: $:^{81}$

Any detailed review of the evidence in a case of this character for the purpose of determining the propriety of the trial court's refusal to direct a verdict would be an idle and useless ceremony in the light of the recent decisions of the Supreme Court. This is so regardless of what we might think of the sufficiency of the evidence in this respect. The fact is, so we think, that the Supreme Court has in effect converted this negligence statute into a compensation law thereby making, for all practical purposes, a railroad an insurer of its employees. (See dissent of Mr. Justice Roberts in Bailey v. Central Vermont Ry., 319 U. S. 350, 358, 63 S. Ct. x062, т066, 87 L. Ed. ז444.)

The Supreme Court, commencing with Tiller v. Atlantic Coastline R. Co., 3 I 8 U. S. 54,63 S. Ct. 444,87 L. Ed. 6 ro, I43 A. L. R. 967 , in a succession of cases has reversed every court (with one exception hereinafter noted) which has held that a defendant was entitled to a directed verdict. In the Tiller case, the Supreme Court reversed the Court of Appeals for the Fourth Circuit, I28 F. 2d 420, which had affirmed the District Court in directing a verdict. The case, upon remand, was again tried in the court below, where a directed verdict was denied. For this denial the Court of Appeals reversed and again the Supreme Court reversed the Court of Appeals, holding that the District Court properly submitted the case to the jury. In Tennant v. Peoria \& P. U. R. Co., 32r U. S. 29, 64 S. Ct. 409, 88 L. Ed. 520, this court reversed the District Court on account of its refusal to direct a verdict, and our decision, I34 F. $2 \mathrm{~d} \mathrm{860,} \mathrm{was} \mathrm{reversed} \mathrm{by} \mathrm{the} \mathrm{Supreme}$ Court. In Bailey v. Central Vermont Ry., 319 U. S. 350,63 S. Ct. I062, 87 L. Ed. I444, the Supreme Court of Vermont held that there should have been a directed verdict for the defendant, and the Supreme Court reversed the decision of that court. In Blair v. Baltimore \& O. R. Co., 323 U. S. 600,65 S. Ct. 545, 89 L. Ed. 490, the Supreme Court reversed the Supreme Court of Pennsylvania which had held that there should have been a directed verdict. In the recent case of Lavender, Administrator, etc., v. Kurn et al., 66 S. Ct. 740 , the Supreme Court reversed the Supreme Court of Missouri which had held that there should have been a directed verdict for each of the defendants.

The only exception to this unbroken line of decisions is Brady v. Southern R. Co., 320 U. S. 476,64 S. Ct. 232, 88 L. Ed. 239, where the Supreme Court of North Carolina was affirmed in its holding that there should have been a directed verdict. This ex-

${ }^{81}$ Id. at $333-334$. 
ception, however, is of little consequence in view of the fact that four members of the court dissented.

The case of Lavender v. Kurn, supra, the latest decision of the Supreme Court under the Federal Employers Liability Act, leaves little room for doubt but that a directed verdict by a trial court or a holding by any court sustaining a directed verdict will not meet with favor, even though the verdict involves speculation and conjecture. In the Lavender case, the Missouri Supreme Court, I89 S. W. 2 d 253, 259, held: “. . . that it would be mere speculation and conjecture to say that Haney was struck by the mail hook, and we are constrained to rule that plaintiff failed to make a submissible case on that question." In response to this holding the Supreme Court states [66 S. Ct. 744]: "It is no answer to say that the jury's verdict involves speculation and conjecture." A reading of the facts of that case, both as related by the Supreme Court and the Supreme Court of Missouri, reveals very clearly that the jury's verdict as to the cause of decedent's death, especially as it applies to the Illinois Central Railroad, amounted to nothing more than a guess on its part.

That the Supreme Court treats the question of negligence and proximate cause as a jury question in this class of cases is clearly shown by a study of these cases. Moreover, not only are these issues to be decided by the jury but its decision is unassailable. In fact, it is difficult to conceive of a case brought under this Act where a trial court would be justified in directing a verdict.

District Judge Lindley dissented from the affirmance, saying, inter alia: ${ }^{\mathbf{8 2}}$

I think the evidence here reflects no proof of an unreasonably unsafe place to work. It seems to me that defendant has never had a trial upon the true issue, namely that alleged in plaintiff's declaration of negligent operation of cars and failure to keep lookout or give a warning. Indeed, the trial proceeded upon a false issue unsupported by any evidence. I would reverse the judgment for a new trial.

Circuit Judge Kerner concurred in the result of the affirmance but would not go along with the criticism of the Supreme Court contained in Judge Major's opinion. He said: ${ }^{83}$

I concur in the result reached and the legal propositions announced. I do not agree, however, that the Supreme Court has converted the Federal Employers' Liability Act into a compensation law and has made a railroad an insurer of its employees.

This statement was purely negative. He did not say what he thought the Supreme Court had done to the law of negligence by its recent decisions. He was less frank but more deferential to the Supreme Court than Judge Major.

It is worthy of note that at the time of this decision Judge Sherman Minton, soon to be appointed to the Supreme Court, was a member of the Court of Appeals for the Seventh Circuit, although he did not sit on this particular case.

\section{The I946 Term}

At the October Term, r946, the Supreme Court returned to its trend in sivor of plaintiffs, with Mr. Justice Black and the bloc of four in charge.

In Jesionowski v. Boston \& Maine R. R., ${ }^{84} \mathrm{Mr}$. Justice Black, in an opinion for the Court, considerably liberalized the doctrine of res ipsa loquitur so as to make

\footnotetext{
${ }^{82}$ Id. at 338 .

${ }^{83}$ Id. at 337 .

s4 329 U. S. 452, decided Jan. 13, 1947.
} 
it more favorable to plaintiffs. Mr. Justice Reed, Mr. Justice Jackson, who had returned from Nuremberg, and Mr. Justice Burton, the sole Republican on the Bench, who had been appointed by President Truman on September 18, I945, and seated on the Court on October I, r945, dissented on the ground that the decision of the Court of Appeals for the First Circuit, below, had correctly applied the rule of res ipsa loquitur and that its judgment should be affirmed.

We should note that at this time Chief Justice Vinson had succeeded Chief Justice Stone, so that the majority of the Court, with Mr. Justice Black, included Chief Justice Vinson and Justices Frankfurter, Douglas, Murphy, and Rutledge.

The Jesionowski case was an action for damages for the death of a brakeman whose duty it was to throw a switch before a train of four cars pushed backward by an engine reached that switch, in order that the four cars would take the siding. There was evidence that he threw the switch and gave the signal to the engineer to back the cars. The Court's opinion admitted that the railroad's evidence was sufficient to authorize, but not compel, the jury to find that the deceased negligently threw the switch while the lead car in the backward movement straddled the switch, with one set of the car wheels on one side of the switch and one on the other. If true, this would mean that the wheels east of the switch would move down the main line and the others would enter the siding when the switch was thrown, causing the derailment in which the brakeman was killed. The opinion admitted that, if the jury had believed the railroad's evidence that the last car was astride the switch when it was thrown, it would have been authorized, under the trial court's charge, to find for the railroad.

There was some speculative evidence that, if a frog about 75 feet east of this switch, operated by a spring mechanism, had failed to work when the wheels passed over it, that might cause a derailment. Some planks and splinters were found on the track either close to the switch or close to the frog, as to which the evidence was in dispute. It appeared that the frog and switch had been in good condition before the derailment and after the derailment, and that cars had been operated and the tracks had been similarly used previously without any similar mishap.

The Court of Appeals for the First Circuit reversed a judgment on a verdict for the plaintiff, ${ }^{85}$ holding that the trial court erred in submitting the case to the jury under the doctrine of res ipsa loquitur. It held that that doctrine has rigidly defined prerequisites, one of which is that to apply it the defendant must have exclusive control of all the things used in an operation which might probably have caused injury. It pointed out that here the railroad did not have exclusive control of all such factors since the deceased had immediate control over the switching and signalling. Mr. Justice Black, for the majority of the Supreme Court, disagreed. $\mathrm{He}$ said that this viewpoint unduly restricted the power of juries to decide questions of fact. He referred to the opinion of the Court of Appeals as embodying "a conceptualistic interpretation of res ipsa loquitur," which unduly narrowed the doctrine as applied by the Supreme Court. His position was that once a jury, having been

${ }^{85}{ }_{154}$ F. $2 d 703$ (Ist Cir. 1946). 
appropriately instructed, finds that the employee's activities did not cause the derailment, the railroad remained as the exclusive controller of all the factors which may have caused the accident. By this means he held that the jury was authorized to find negligence from the mere fact that the accident occurred.

In Ellis v. Union Pacific R. R., ${ }^{86}$ the Court, in an unanimous decision, opinion by Mr. Justice Douglas, reversed a judgment of the Supreme Court of Nebraska, which had reversed a judgment on a jury verdict for plaintiff for insufficiency of evidence to show negligence. The Supreme Court held that that decision was in conflict with the Lavender case.

It is unnecessary here to review the facts. This writer cannot assert that the Supreme Court's decision was wrong, but only that it was fairly debatable. The interesting thing is that in the opinion the Court, for the first time, returned to its decision in the Brady case and relied on that case as a controlling precedent. Mr. Justice Douglas, who had joined the dissenters in the Brady case, said: ${ }^{87}$

The Act does not make the employer the insurer of the safety of his employees while they are on duty. The basis of his liability is his negligence, not the fact that injuries occur. And that negligence must be "in whole or in part" the cause of the injury. 45 U. S. C. $\$ 5$ I; Brady v. Southern R. Co., 320 U. S. 476, 484. Whether those standards are satisfied is a federal question, the rights created being federal rights. Brady v. Southern R. Co., supra; Bailey v. Central Vermont R. Co., 3I9 U. S. 350.

Perhaps Mr. Justice Douglas had read the criticism by Judge Major, of the Seventh Circuit Court of Appeals, of the Supreme Court's decisions since Brady. In any case he returned to that case and reaffirmed it. But in the instant case he reversed the Nebraska court on the ground that the evidence was controverted and sufficient to support the verdict, under the doctrine of the Lavender case.

In Myers v. Reading Co., ${ }^{88}$ the unanimous Court, opinion by Mr. Justice Burton, reversed a decision of the Court of Appeals for the Third Circuit, which had affirmed a district court's entry of judgment for defendant, notwithstanding jury verdict for plaintiff. It held that the evidence was sufficient to warrant the jury in holding the defendant railroad liable under the FELA and the Safety Appliance Acts. This time, interestingly enough, the Supreme Court cited, reaffirmed, and relied upon both the Brady case and the Lavender case and left other courts and the bar still to speculate as to what the law was as between those two wholly inconsistent cases.

At the 1946 term no railroad won a case. All three decisions were in favor of plaintiffs. But the Court, in terms, had reaffirmed the Brady case, without recognizing however any inconsistency between it and the Lavender case, which also was reaffirmed.

\section{The r947 Term}

At the October Term, I947, the Supreme Court developed a new technique in favor of plaintiffs who had lost in lower courts. That was to grant the losing

${ }^{86} 329$ U. S. 649 , decided Feb. 3, I947.

${ }^{88} 33$ I U. S. 477 , decided June 2, 1947.

${ }^{87} \mathrm{Id}$. at 653 . 
plaintiff's petition for certiorari and, on that petition and the brief in support thereof, to reverse by per curiam opinion, without hearing the railroad on argument.

This was done in Lillie v. Thompson. ${ }^{89}$ The Court did not even note appearances for the respondent railroad. It held that the evidence was sufficient to go to the jury, with no discussion of precedents except to cite the Restatement of the Law of Torts in a footnote. No plaintiff or plaintiff's counsel could complain of that technique.

Callen v. Pennsylvania $R . R .{ }^{90}$ is not within the scope of this paper, because it only involved the question of the validity of a release.

In Anderson v. Atchison, T.\& S. F. Ry., ${ }^{91}$ the Court again resorted to its new technique and merely on the certiorari papers, and without hearing or argument, reversed the Supreme Court of California, which had affirmed a trial court judgment for the railroad on a holding that plaintiff's complaint did not state a cause of action under the FELA. It held that a complaint was sufficient which alleged that a conductor disappeared from a moving train in very cold weather at a time when his duty required his presence on the rear vestibule, that his absence was discovered by other trainmen, that they negligently failed to make prompt efforts to have him rescued, and that he died from the resulting exposure.

The per curiam opinion cited and relied on the Tiller, Bailey, Blair, and Lillie cases but made no mention of the Brady case.

\section{The 1948 Term}

At the October Term, I948, for the first time in five years, since the Brady case in I943, a railroad won an FELA case in the Supreme Court, Eckenrode v. Pennsylvania $R$. R., ${ }^{92}$ by a per curiam opinion. The bloc of Justices Black, Douglas, Murphy, and Rutledge of course dissented.

A district court set aside a verdict for the plaintiff and entered judgment for the railroad. The Court of Appeals for the Third Circuit affirmed, and after a rehearing again affirmed, one judge dissenting. ${ }^{93}$

The Supreme Court, affirming that judgment, merely said: ${ }^{94}$

There is a single question presented to us: Was there any evidence in the record upon which the jury could have found negligence on the part of the respondent which contributed, in whole or in part, to Eckenrode's death? Upon consideration of the record, the Court is of the opinion that there is no evidence, nor any inference which reasonably may be drawn from the evidence, when viewed in a light most favorable to the petitioner, which can sustain a recovery for her. Accordingly, the judgment is Affirmed.

That was helpful and no doubt entirely satisfactory to the Pennsylvania Railroad. It was not very illuminating to other railroads or their counsel, or to other courts, as to what was left of the old law of negligence. The Court of Appeals set out the facts in evidence in this case ( 164 F. $2 \mathrm{~d}$ at 998-999), and they were hardly as speculative as to railroad negligence as were the facts in the Lavender case (327

sv 332 U. S. 459 , decided Nov. 24, 1947.

${ }^{01} 333$ U. S. $82 \mathrm{r}$, decided April 26, r948.

${ }^{03}{ }_{164}$ F. $2 d 996$ ( 3 d Cir. I947).

${ }^{90} 332$ U. S. 625 , decided Jan. 12,1948 .

92 335 U. S. 329 , decided Nov. '15, 1948 .

${ }^{94} 335$ U. S. at 330 . 
U. S. 645). Nevertheless the case was highly important as the first break in a fiveyear uniform trend of decisions against railroads and left some hope that a railroad, in a proper case, might have a bare chance of getting a five-to-four decision in its favor. Nothing has ever indicated any hope of any railroad in any FELA case, however meritorious, getting a single vote in its favor from the bloc of Justices Black, Douglas, Murphy, and Rutledge. Not one of them has ever, to the present writing, joined in a judgment in favor of a railroad in any case under the FELA.

In Coray v. Southern Pacific Co., ${ }^{95}$ the Court, in a unanimous decision, opinion by Mr. Justice Black, reversed the Supreme Court of Utah, which had ${ }^{06}$ affirmed a trial court in directing a verdict for the railroad. The Supreme Court held that the undisputed evidence established that the employee was killed when a motordriven track car, on which he was following a train, crashed into the train when it stopped suddenly and unexpectedly because of a defective air-brake appliance. On such facts it was held that a case was made for the jury under the Safety Appliance and Employers' Liability Acts. The state courts had held that the protection of the Safety Appliance Act's requirement as to air-brakes on the train did not cover and protect an employee on the following motor car. The Supreme Court disagreed.

By the time of the next case, Wilkerson v. McCarthy, ${ }^{9 \tau}$ it is clear that not only Mr. Justice Douglas but all the other members of the Court had read the opinion by Judge Major of the Seventh Circuit in Griswold v. Gardner, containing his criticism of the recent trend of Supreme Court decisions, since the Supreme Court, in the Wilkerson case, made a considerable point of undertaking to answer that criticism.

In the Wilkerson case the Court, by a seven-to-two decision, opinion for the Court by Mr. Justice Black, separate dissenting opinions by Chief Justice Vinson and by Mr. Justice Jackson, reversed the Supreme Court of Utah, which had affirmed ${ }^{98}$ a district court's direction of a verdict for the defendant railroad. The facts were complicated and the evidence presented a close and debatable question as to whether it was sufficient to go to the jury and to support a verdict in favor of the plaintiff. Mr. Justice Black said that the opinion of the Utah Supreme Court strongly indicated, as the dissenting judge on that court pointed out, that its affirmance of direction of verdict for the defendant rested on that court's independent resolution of conflicting testimony. He held that that was contrary to the Supreme Court's decisions in the Lavender, Bailey, and Tiller cases. He cited Brady v. Southern Ry. under the rubric "and see." We need not here detail the evidence. It is sufficient for our purposes that the majority of the Court thought that it was sufficient to support a verdict for the plaintiff, whereas Chief Justice Vinson and Mr. Justice Jackson vigorously asserted that there was no evidence, nor any inference which reasonably might be drawn from the evidence, when viewed in the light most favorable to the plaintiff, which could sustain a verdict for him.

${ }^{25} 335$ U. S. 520 , decided Jan. 3 , 1949.

${ }^{27} 336$ U. S. 53 , decided Jan. 3 I, I949.
${ }^{00}$ I 85
${ }^{\circ 8}$ P. $2 \mathrm{~d} 966_{3}$ (1947). 
The interesting feature of the case lies in the efforts which the Court made to defend itself against widespread suggestions, and in particular the suggestion of Judge Major, that the Supreme Court's recent decisions under the FELA had changed that act from a negligence act to an act in the nature of a workmen's compensation act, imposing liability regardless of fault. Addressing himself to this question, Mr. Justice Black, in the opinion of the Court, said: ${ }^{99}$

Much of respondents' argument here is devoted to the proposition that the Federal Act does not make the railroad an absolute insurer against personal injury damages suffered by its employees. That proposition is correct, since the Act imposes liability only for negligent injuries. Cf. Coray v. Southern Pac. Co., 335 U. S. 520. But the issue of negligence is one for juries to determine according to their finding of whether an employer's conduct measures up to what a reasonable and prudent person would have done under the same circumstances. And a jury should hold a master "liable for injuries attributable to conditions under his control when they are not such as a reasonable man ought to maintain in the circumstances," bearing in mind that "the standard of care must be commensurate to the dangers of the business." Tiller v. Atlantic C. L. R. Co., 3 I 8 U. S. 54, 67 .

There are some who think that recent decisions of this Court which have required submission of negligence questions to a jury make, "for all practical purposes, a railroad an insurer of its employees." See individual opinion of Judge Major, Griswold v. Gardner, I55 F. 2d 333, 334. But see Judge Kerner's dissent from this view at p. 337 and Judge Lindley's dissenting opinion, pp. $337-33^{8}$. This assumption, that railroads are made insurers where the issue of negligence is left to the jury, is inadmissible. It rests on another assumption, this one unarticulated, that juries will invariably decide negligence questions against railroads. This is contrary to fact, as shown for illustration by other Federal Employers' Liability cases, Barry v. Reading Co., I47 F. 2d I29, cert. denied, 324 U. S. 867; Benton v. St. Louis-San Francisco R. Co., I82 S. W. 2d 6r, cert. denied, 324 U. S. 843. And cf. Bruner v. McCarthy, I05 Utah 399, I42 P. $2 \mathrm{~d}$ 649, cert. dismissed for reasons stated, 323 U. S. 673 . Moreover, this Court stated some sixty years ago when considering the proper tribunal for determining questions of negligence: "We see no reason, so long as the jury system is the law of the land, and the jury is made the tribunal to decide disputed questions of fact, why it should not decide such questions as these as well as others." Jones $v$. East Tennessee $R$. Co., x28 U. S. 443, 445. And peremptory instructions should not be given in negligence cases "where the facts are in dispute, and the evidence in relation to them is that from which fair-minded men may draw different inferences." Washington \& G. R. Co. v. McDade, 135 U. S. 554, 572. Such has ever since been the established rule for trial and appellate courts. See Tiller $v$. Atlantic C. L. R. Co., 378 U. S. 54, 67, 68. Courts should not assume that in determining these questions of negligence juries will fall short of a fair performance of their constitutional function. In rejecting a contention that juries could be expected to determine certain disputed questions on whim, this Court, speaking through Mr. Justice Holmes, said: "But it must be assumed that the constitutional tribunal does its duty and finds facts only because they are proved." Aikens $v$. Wisconsin, 195 U. S. 194, 206.

Mr. Justice Frankfurter concurred in a separate opinion in which he stressed the fact that it is the trial judge's function to determine whether the evidence in its entirety would rationally support a verdict for the plaintiff, assuming that the jury

${ }^{00} 336$ U. S. at $6 \mathrm{x}-63$. 
took, as it would be entitled to take, a view of the evidence most favorable to the plaintiff. But he pointed out that there is no bright line dividing negligence from non-negligence, that questions of negligence are questions of degree, often very nice differences of degree, and that judges of competence and conscience in the past have disagreed, and in the future will disagree, on such questions. Having made these observations, he asserted that the difficulties in these cases derive largely from what he called "the outmoded concept of 'negligence' as a working principle for the adjustments of injuries inevitable under the technological circumstances of modern industry." He went further and asserted his own view that this is a cruel and wasteful mode of dealing with industrial injuries and that it has long been displaced in industry generally by the insurance principle that underlies workmen's compensation laws. He added: $:^{100}$

It is, of course, the duty of courts to enforce the Federal Employers' Liability Act, however outmoded and unjust in operation it may be. But so long as negligence rather than workmen's compensation is the basis of recovery, just so long will suits under the Federal Employers' Liability Act lead to conflicting opinions about "fault" and "proximate cause." The law reports are full of unedifying proof of these conflicting views, and that too by judges who seek conscientiously to perform their duty by neither leaving everything to a jury nor, on the other hand, turning the Federal Employers' Liability Act into a workmen's compensation law.

Upon these observations and upon his study of the present case and previous cases under the Act, Mr. Justice Frankfurter drew the conclusion that the Supreme Court ought not to grant certiorari in any of these cases that involves no more than its particular facts. He thought this had appeared to be the situation in the Wilkerson case and that the petition for certiorari ought to have been dismissed. He expressed a serious concern because this was "the thirtieth occasion in which a petition for certiorari has been granted during the past decade to review a judgment denying recovery under the Federal Employers' Liability Act in a case turning solely on jury issues." He thought the Supreme Court, in view of the mounting burden of its business, ought to relieve itself of cases of this class.

Mr. Justice Burton, having concurred in the Court's opinion, also joined in Mr. Justice Frankfurter's opinion.

Mr. Justice Douglas filed a separate concurring opinion, which he introduced by saying: "While I join in the opinion of the Court, I think it appropriate to take this occasion to account for our stewardship in this group of cases." $\mathrm{He}$ declared that the FELA was designed to put on the railroad industry some of the cost for the legs, eyes, arms, and lives which it consumed in its operations. He admittted that not all these costs were imposed, for the Act did not make the employer an insurer; that the liability which it imposed was only the liability for negligence. However, he expressed the view that that purpose had not been given a friendly reception in the courts. ${ }^{101} \mathrm{He}$ asserted that the Supreme Court itself had led the ${ }^{100} \mathrm{Id}$. at 66.

${ }^{102}$ Citing, particularly, Seaboard Air Line v. Horton, 233 U. S. 492 (1914); Toledo, St. L. \& W. R. R. v. Allen, 276 U. S. I65 (1928); and the review of the cases in Tiller v. Atlantic Coast Line R. R., 318 U. S. $54,62-67$ (1943). 336 U. S. at 69 . 
way in overturning jury verdicts rendered for employees." ${ }^{102}$ "And so it was," he asserted, "that a goodly portion of the relief which Congress had provided employees was withheld from them."

Mr. Justice Douglas then proceeded to attempt a further answer to the charge that the Supreme Court had converted the Liability Act into a Workmen's Compensation Act. He himself undertook a review of the cases coming to the Supreme Court from the $x 943$ term to the I948 term, setting that review out in a list published as an appendix ${ }^{103}$ to his opinion, which, he said, shows a record more faithful to the design of the Act than previously prevailed.

The defect in his appendix is that he padded it with long lists of cases in which the Supreme Court had merely denied certiorari, although the Supreme Court has always held that denial of certiorari is no decision on the merits of a case and is not to be taken as a precedent on the merits.

Eliminating these mere denials of certiorari, his analysis of the decisions since I943 corresponds entirely with our analysis in this paper, in showing that every case had been decided against the railroad and in favor of the plaintiff except the Brady case and the Eckenrode case, with the one exception that he also listed Hunter v. Texas Electric Ry. Co., ${ }^{104}$ which was a mere per curiam opinion in favor of the defendant, not showing what question was in issue and not even showing that the FELA was involved, but showing that Justices Black, Douglas, Murphy, and Rutledge had dissented.

In a separate dissenting opinion, Mr. Justice Jackson differed with the Court's opinion and with Mr. Justice Douglas' separate concurring opinion, saying: ${ }^{105}$

This Court now reverses and, to my mind at least, espouses the doctrine that any time a trial or appellate court weighs evidence or examines facts it is usurping the jury's function. But under that rule every claim of injury would require jury trial, even if the evidence showed no possible basis for a finding of negligence. Determination of whether there could be such a basis is a function of the trial court, even though it involves weighing evidence and examining facts. I think we are under a duty to examine the record impartially if we take such cases and to sustain the lower courts where, as here, a finding of negligence would obviously be without basis in fact.

I am not unaware that even in this opinion the Court continues to pay lip service to the doctrine that liability in these cases is to be based only upon fault. But its standard of fault is such in this case as to indicate that the principle is without much practical meaning.

Mr. Justice Jackson then proceeded to demonstrate in inimitable fashion that there was no sufficient evidence of negligence in the Wilkerson case, and to that demonstration we invite the reader's consideration. He then added:106

If in this class of cases, which forms a growing proportion of its total, this Court really is applying accepted principles of an old body of liability law in which lower courts

${ }^{103}$ Citing Chicago, M. \& St. P. R. R. v. Coogan, 27 I U. S. 472 (1926); Missouri Pac. R. R. v. Aeby, 275 U. S. 426 (I928); and New York Central R. R. v. Ambrose, 280 U. S. 486 (I930). 336 U. S. at 69. 103336 at $71-73$.

${ }^{100} 336$ U. S. at $75-76$.

${ }_{104} 332$ U. S. 827 (I947).

${ }^{100} I d$. at 76. 
are generally experienced, I do not see why they are so baffled and confused at what goes on here. On the other hand, if this Court considers a reform of this law appropriate and within the judicial power to promulgate, I do not see why it should constantly deny that it is doing just that.

The last statement by Mr. Justice Jackson is accepted as the basic text of this paper, without further elaboration by the present writer.

In Reynolds $v$. Atlantic Coast Line R. $R .,{ }^{107}$ by a per curiam opinion, the Supreme Court affirmed the Supreme Court of Alabama in a holding that a cause of action under the FELA was not stated by a complaint which merely alleged that the defendant railroad's negligence caused the deceased employee to perform additional work of the same kind he normally performed, without alleging that this additional work contained any hazards other than those usual to the occupation.

Even in this plain case the bloc of Justices Black, Douglas, Murphy and Rutledge dissented.

Mr. Justice Frankfurter was of the opinion that the certiorari should not have been granted, in line with his separate opinion in the Wilkerson case.

The r948 Term ended, as far as this class of cases is concerned, with an epochmaking decision, Mr. Justice Rutledge writing for the majority, Justices Frankfurter, Reed, Jackson, and Burton concurring only in part, in the case of Urie v. Thompson, ${ }^{108}$ holding, for the first time, that the coverage of the FELA and of the Boiler Inspection Act is not confined to injuries resulting from accidents, but includes injuries in the nature of occupational diseases, such as silicosis. The concurring justices agreed with this holding in so far as concerns "injuries" as used in the FELA, but disagreed as to "accidents" as used in the Boiler Inspection Act.

The majority, however, went the whole way as to both acts and also held that the fact that the plaintiff's contraction of silicosis resulted from the inhalation of silica dust over a period of thirty years, so that he may have had silicosis without knowing it for more than three years before he brought his suit, did not bar his claim under the FELA, when the time which elapsed between his discovery of his condition and the filing of suit did not exceed three years.

This case is not strictly within the coverage of this paper. It did not deal as such with the law of negligence. The opinion by Mr. Justice Rutledge assumed that the occupational disease of silicosis would only be within the coverage of the FELA if caused by railroad negligence. As to the Boiler Inspection Act, however, he held that negligence need not be proved, that any violation of ICC rules under that Act which caused an engineer to contract silicosis was compensable in spite of the fact that the Boiler Inspection Act in terms only covered "accidents," not "injuries" as did the FELA. It was specifically held that the coverage of the Boiler Inspection Act, as applied to occupational diseases, was no narrower than that of the FELA, although the former imposed an absolute liability not dependent on proof of negligence.

${ }^{207} 336$ U. S. 207 , decided Feb. 14, 1949.

${ }^{108} 337$ U. S. 163, decided May 31, 1949. 
The great significance of the case was that it was one of novel impression and opened up a wholly new field of coverage of occupational diseases under the two acts.

In his opinion, "concurring in part," joined in by Justices Reed, Jackson, and Burton, Mr. Justice Frankfurter again went out of his way to refer to the FELA as "an antiquated and uncivilized basis for working out rights and duties for disabilities and deaths inevitably due to the conduct of modern industry." That his view be not abridged, his opinion is quoted as follows: ${ }^{100}$

At the risk of wearisome reiteration it is relevant to say again that the common-law concept of negligence is an antiquated and uncivilized basis for working out rights and duties for disabilities and deaths inevitably due to the conduct of modern industry. In the conscious or unconscious endeavor not to have the human cost of industry fall with cruel injustice upon workers and their families, the law of negligence gives rise to endless casuistry. So long as the gamble of an occasional heavy verdict is not replaced by the security of a modern system of insurance, courts must continue to apply the notion of negligence in situations for which it was never intended. Therefore, if a claim is made that an injury is causally related to a carrier's failure to maintain standards of care appropriate for employment on a railroad, the Federal Employers' Liability Act entitles an employee to establish that claim to a jury's satisfaction. Damages are recoverable under that Act for suffering "injury." That term, it seems to me, is sufficiently broad to include bodily injury which nowadays is more specifically characterized as "occupational disease." Accordingly, I agree that recovery may be had under the Federal Employers' Liability Act for silicosis, where the facts sustain such a claim, as is illustrated by the case of Sadowski v. Long Island R. Co., 292 N. Y. 448, 55 N. E. 2d 497.

On the other hand, I agree with the Missouri Supreme Court that occupational diseases cannot be fitted into the category of "accidents" for which the Boiler Inspection Act devised a scheme of regulation and a basis of liability. 36 Stat. 9r3, as amended, 45 U. S. C. $\$ \$ 22-34$. I think I appreciate the humane impulse which seeks to bring occupational diseases within such a regime. But due regard for the limits of judicial interpretation precludes such free-handed application of a statute to situations outside its language and its purpose. To do so, moreover, is, I believe, a disservice to the humane ends which are sought to be promoted. Legislation is needed which will effectively meet the social obligations which underlie the incidence of occupational disease. See National Insurance (Industrial Injuries) Act, 1946,9 \& xo Geo. 6, 488, particularly Part IV. The need for such legislation becomes obscured and the drive for it retarded if encouragement is given to the thought that there are now adequate remedies for occupational diseases in callings subject to Congressional control. The result of the present decision is to secure for this petitioner the judgment which the jury awarded him. It does not secure a proper system for dealing with occupational diseases.

The 1949 Term

Two deaths between the 1948 and the I949 Terms, that of Mr. Justice Murphy, on July I9, I949, and that of Mr. Justice Rutledge, on September Io, I949, broke up the bloc of four justices who had always stood together against railroads and in favor of plaintiffs in these cases. They were succeeded on the Court respectively by Mr. Justice Clark and Mr. Justice Minton.

${ }^{100}$ Id. at 196-197. 
The first FELA case at the 1949 Term, Boyd v. Grand Trunk Western R. R., ${ }^{110}$ did not deal with the law of negligence. It held, in a per curiam opinion, that an agreement between a railroad and an employee injured by its negligence, which limits the venue of any action thereafter brought by the employee under the Act, deprives him of his right to bring an action in any forum authorized by the Act and is void.

In the next case, Brown v. Western Ry. of Alabama, ${ }^{111} \mathrm{Mr}$. Justice Black led the majority of the Court, indeed with no help from Mr. Justice Douglas, who took no part in the consideration or decision of the case. Justices Frankfurter and Jackson dissented. The split was over an interesting question as to whether a state court of Georgia, by giving effect to a general principle of pleading uniformly enforced in that state, had legitimately given force to a "procedural" rule of that state or had cut deeper than procedure and had impaired the plaintiff's "substantive" right under the FELA.

The state court sustained a general demurrer to plaintiff's complaint under the FELA which merely alleged that plaintiff was injured while in the performance of his duties when he stepped on a large clinker lying alongside the track in the railroad yard. It held that the mere presence of a large clinker in a railroad yard could not be said to constitute an act of negligence and that, so far as the allegations of the complaint showed, the sole cause of the accident was the act of the plaintiff in stepping on this large clinker, which he was able to see and could have avoided. The state court reached those conclusions by following a Georgia rule of practice to construe pleading allegations "most strongly against the pleader."112

Mr. Justice Black, for the majority of the Supreme Court, held that this construction of the pleading was not binding on his Court. He recognized, as did the dissenters, that it is troublesome to find the line between procedural and substantive rights, but he held that the Supreme Court will construe a complaint under the FELA most favorably in favor of the plaintiff and that "strict local rules of pleading cannot be used to impose unnecessary burdens upon rights of recovery authorized by federal laws." Accordingly the Court reversed the Georgia court. But it carefully limited its opinion to reversal so that plaintiff could have a trial on his complaint, cautioning that upon such a trial "the evidence offered may or may not support inferences of negligence."

It is interesting that Mr. Justice Black cited ${ }^{113}$ Brady v. Southern Ry. (320 U. S. 476,479 ), in support of his holding that "Should this Court fail to protect federally created rights from dismissal because of over-exacting local requirements for meticulous pleadings, desirable uniformity in adjudication of federally created rights could not be achieved."

The dissenters, Justices Frankfurter and Jackson, thought that the Georgia court had not disrespected the law of the land; that, while Georgia's rule of pleading

\footnotetext{
${ }_{110}{ }_{33} 8$ U. S. 263 , decided Nov. 7, 1949.

112 Brown v. Western Ry. of Alabama, 77 Ga. App. 780,49 S. E. $2 d 833$ (1948).

${ }^{111} 338$ U. S. 294 , decided Nov. $21,1949$.

213338 U. S. 299.
} 
might have reflected "something of the pernicketiness with which seventeenthcentury common law read a pleading," nevertheless that was not a denial of a federal right, especially where the state rule of pleading was uniformly enforced in actions in the state courts. They said that this particular plaintiff had chosen the Georgia courts as a forum, with full knowledge of the niceties of pleading required by Georgia, had not amended his complaint, but had elected to stand on his complaint against a general demurrer, and that the Georgia court could not fairly be said to have deprived him of a substantive federal right.

It is the view of this writer that the dissenting opinion might as soundly have been the opinion of the Supreme Court as the majority opinion. In this close case the trend in favor of liberalizing the law in favor of plaintiffs continued.

In $O^{\prime}$ Donnell v. Elgin, J. \& E. Ry., ${ }^{114} \mathrm{Mr}$. Justice Jackson, surprisingly enough, in his opinion for the majority, shocked railroad lawyers by doing what can only be described as rewriting the Automatic Coupler Act ${ }^{115}$ to make it apply to something which Congress clearly had not condemned. Mr. Justice Jackson is not much given to the practice of judicial legislation, rewriting acts of Congress, and he has often spoken out against it in vigorous terms. Yet, just as even Homer nods, he nodded in this case and wrote new language into the Act.

Justices Frankfurter, Douglas, and Minton took no part in the consideration or decision of the case. Justices Reed and Burton dissented. So the case was really shocking to railroad lawyers, since an actual minority of four justices of the Court rewrote the statute to take care of this plaintiff's case.

The only requirement Congress had made in the statute was to prohibit railroads using cars "not equipped with couplers coupling automatically by impact, and which can be uncoupled without the necessity of men going between the ends of the cars." That was all Congress said in the Act. That was a severe enough requirement, in all good conscience, carrying its absolute liability for any breach regardless of negligence, because science has never been able to devise any such coupler which will always couple automatically by impact, as all railroad mechanical men and all railroad lawyers know. The finest coupler that science has been able to produce sometimes will couple automatically on impact and sometimes will not. Often a half dozen or more tries have to be made before the best coupler will couple automatically on impact, especially if the impact takes place on a curve.

Not content with that severe and often impossible requirement, the minority of four members of the Court added to the statute a requirement in terms, not enacted by Congress, that the cars must be equipped with couplers that "will remain coupled until set free by some purposeful act of control."116 The dissenters pointed out that Congress might have so legislated but that it did not do so.

O'Donnell met an unwitnessed death while working in defendant's yard as a member of its switching crew. When last seen, he was going to adjust the couplers

${ }^{114} 33^{8}$ U. S. $3^{84}$, decided Dec. I2, 1949.

11027 STAT. 531 (I893), 45 U. S. C. $\$ 2$ ( 1946 ).

${ }^{116} 338$ U. S. 384,389 . 
on certain cars which previously had failed to couple by impact. Shortly after his departure, as the result of the breaking of a coupler, two cars broke loose from a cut of cars that was being moved in a switching operation. Running free, they collided with other standing cars and drove them against those whose couplers decedent had said he was going to adjust. That he had gone between them to adjust couplers was suggested by the fact that they actually coupled upon impact with the colliding cars, though they previously had failed to do so.

The Court's opinion concerned itself only with the effect accorded by the trial court's instructions to the breaking of the coupler which let loose the two cars. The trial court refused to instruct that a breaking of the coupler was negligence per se or a violation of the statute. The Court of Appeals for the Seventh Circuit sustained this refusal, saying, ${ }^{117}$

... we do not believe the Act required defendant to furnish couplers that would not break. We think the true rule is that where a coupler does break, the jury may, if they think it reasonable under all the circumstances, infer that the coupler was defective and was furnished and used in violation of the Act. The cases go no further than to hold that from the breaking of a coupler the jury may infer negligence.

Mr. Justice Jackson and the three other members of the Court who joined him disagreed and reversed. He admitted that ${ }^{118}$ "A close and literal reading of the ... Act . . . suggests that two functions only are required of couplers: that they couple automatically by impact and that they uncouple without requiring men to go between the ends of the car." It will be seen that this absolutely was the only requirement of the Act. Mr. Justice Jackson admitted that "this construction finds some support in the decisions." Instead of "some support" he cited four decisions of the Supreme Court and four from district courts or federal courts of appeals. But he said that courts at other times have held that failure of couplers to remain coupled until released constitutes or evidences a violation of the Act, citing some nine cases in lower federal and state courts. "This appears," he said, "also to have been the view of this Court in the only case of this nature ever before it. Minneapolis \& St. Louis R. Co. v. Gotschall, 244 U. S. 66."

To rewrite the statute, Mr. Justice Jackson plainly gave attention to what he thought Congress ought to have done, rather than to what it did do, in writing the safety statute. He said: $:^{119}$

It is hard to think of a coupler defect in which greater danger inheres to workmen, travelers and all to whom the railroad owes a duty, than one which sets cars running uncontrolled upon its tracks. We find it difficult to $\operatorname{read}^{120}$ the Safety Appliance Act to require that cars be equipped with appliances which couple automatically by impact and which may be released without going between the end of cars, but which need not remain coupled in the meantime. The Act so construed would guard against dangers incident to effecting an engagement or disengagement while ignoring the even greater hazards

${ }^{217}$ 17t F. 2d 973, 976 (7th Cir. 1948).

${ }^{118} 338$ U. S. at $387-388$.

110 Id. at $388-389$.

${ }^{120}$ Obviously meaning "we do not like to read. . . ." 
which can result from the failure of a coupling to perform its main function, which is to stay coupled until released.

That was an appropriate reasoning to submit to Congress in support of an amendment of the statute. It was hardly a competent inducement to the Court to rewrite the statute by adding to it what Congress did not write into it, as Mr. Justice Jackson did in the next sentence of his opinion, "We hold that the Safety Appliance Act requires couplers which, after a secure coupling is effected, will remain coupled until set free by some purposeful act of control."

This case left railroads and railroad lawyers to speculate, not only as to how much further the Supreme Court was going in rewriting the common law of negligence, but also as to how much further it was going in rewriting acts of Congress, in favor of plaintiffs.

The decision in the O'Donnell case was given further point for plaintiffs and further dangers for railroads by the decision in the next case, Carter v. Atlanta $\mathcal{E}$ St. A. B. $R y .{ }^{121}$ decided the next week, December I9, I949, which held that the duty imposed by the coupler provision of the Safety Appliance Act is an absolute duty unrelated to negligence, and that the absence of a "defect" in a coupler cannot aid the railroad if the coupler was properly set and failed to couple automatically by impact. Mr. Justice Clark wrote the opinion for the Court, reversing the Court of Appeals for the Fifth Circuit which had affirmed the district court in taking away from the jury that phase of the case on its view that there was no evidence to establish any causal connection between the failure of the coupler to couple and the injuries suffered by the plaintiff. ${ }^{122}$

Mr. Justice Reed dissented on his view that the failure of the automatic coupler to fasten on the first impact was not a proximate cause of the injury. "The failure," he said, "did not contribute to the injury. That was caused by a too rapid coupling on the second effort."123

Mr. Justice Douglas took no part in the consideration or decision of this case.

Mr. Justice Frankfurter repeated his position that the writ of certiorari was improvidently granted and should have been dismissed, again paying his lack of respect to "the anachronistic Federal Employers' Liability Act" based on negligence and involving "inevitably casuistic efforts to apply the concepts of 'negligence,' 'proximate cause' and 'contributory negligence' which served well enough employeremployee relations which have long since ceased." He again plumped for the substitution of a workmen's compensation act by Congress, but, of course, not by judicial legislation by the Court. ${ }^{124}$

Again in Affolder v. New York, C. \& St. L. R. R., ${ }^{125}$ the Court held to the same effect in another opinion by Mr. Justice Clark. It also held that $\$ 80,000$ was not an excessive verdict for the loss of a leg.

Mr. Justice Reed and Mr. Justice Jackson dissented. Mr. Justice Douglas took

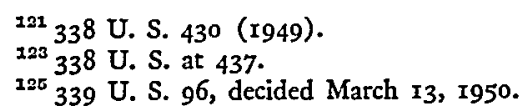


no part. Mr. Justice Frankfurter again thought that the writ of certiorari should have been dismissed as improvidently granted, and Mr. Justice Jackson also agreed with that view.

In his separate dissent, however, Mr. Justice Jackson pointed out that the Court of Aopeals thought the trial court's charge as a whole "very probably gave the jury the impression" that it need only find that two cars failed to couple on impact to establish a violation of the coupler provision of the Safety Appliance Act. "This," he said, "as the Court recognizes, is not the law. Before a failure to couple establishes a defective coupler, it must be found that it was properly set so it could couple. If it was not adjusted as such automatic couplers must be, of course the failure is not that of the device."126

Mr. Justice Jackson had learned some of the facts of life about couplers since his opinion for the Court in the O'Donnell case. Evidently the majority of the Court had not.

The 1950 Term

In Moore v. Chesapeake \& $O . R y .{ }^{127}$ the Court, in an opinion by Mr. Justice Minton, returned to the law as it had been consistently declared by the "old court" and as late as in the Brady case in I943, broke the long trend of decisions in favor of plaintiffs by a soundly reasoned decision, and, for the first time since Brady, clearly indicated that the law of negligence had not been destroyed and that the Court has no intention of administering the FELA as a workmen's compensation act as long as Congress leaves it a negligence statute.

Justices Black and Douglas, the remaining two of the old bloc of four, dissented. Mr. Justice Reed took no part. Mr. Justice Frankfurter again thought the writ should have been dismissed as improvidently granted, for the reasons he had expressed in the Carter and in the Affolder cases.

The district court had granted the defendant judgment notwithstanding the verdict for plaintiff. The Court of Appeals for the Fourth Circuit affirmed. ${ }^{128}$ The Supreme Court affirmed.

Plaintiff's intestate was a brakeman in switching yards. The day was fair. At about 3:50 p.m., the crew with which he was working undertook its first car movement of the day. An engine and tender were headed into Track 12, and the front end of the engine was coupled onto 33 loaded freight cars which were to be moved out initially upon the straight track referred to as the ladder track. The switch at the junction of Track 12 and the ladder track was properly aligned for the train to pass onto the ladder track. Who aligned the switch did not appear.

Decedent gave the signal for the engine to back out of Track 12 with the cars. It moved out in a westerly direction, with the rear of the tender as the front of the moving train. Decedent was standing on a footboard at the rear of the tender, his back to the tender; the outer edge of the footboard was about ten inches in

${ }^{128} 184$ F. $2 d$ I76 (4th Cir. 1950). 
from the outer edge of the tender and about a foot above the rail. The engineer was in his seat on the same side of the train as the footboard on which decedent was standing. The engineer was turned in the seat and leaning out the side cab window, looking in the direction in which the train was moving. Decedent's duty as he rode on the footboard was to give signals to the engineer, who testified that he could at all times see the edge of the arm and shoulder of decedent. To be thus seen and in a position to give signals, decedent had to extend outward beyond the edge of the tender, supporting himself partly by a handrail; otherwise the tender, the top of which was eight feet seven inches above the footboard, would have obstructed the engineer's view of him altogether.

The engineer testified that as the train approached Switch I2 at about five miles per hour, having moved ten or twelve car lengths, he saw decedent slump as if his knees had given way, then right himself, then tumble forward in a somersault toward the outside of the track. The engineer testified that he then made an emergency stop in an unsuccessful effort to avoid injuring decedent. The train ran the length of the tender and engine and about a car length and a half before it stopped at a point about an engine or car length past the switch on the ladder track. Decedent died immediately of the injuries received.

On these facts the Supreme Court reaffirmed what was said but not applied in Tennant v. Peoria \& P. U. Ry. (32I U. S. 29, 32) to the effect that, in order to recover under the Act, it was incumbent upon the plaintiff to prove negligence of the defendant which caused the fatal accident. The negligence alleged by the plaintiff was that defendant's engineer made a sudden and unexpected stop without warning, "thereby causing decedent to be thrown from a position of safety on the rear of the tender" into the path of the train.

Holding that the evidence was not sufficient to carry this allegation to the jury, Mr. Justice Minton, writing for the Court, said: ${ }^{120}$

It is undisputed that only one stop of the train was made and that a sudden stop without warning. The engineer was the only witness to the accident and was called to testify by petitioner. He testified that he saw decedent fall from the tender and that he made an emergency stop in an attempt to avoid injuring him. He testified that he received no signal to stop and had no reason to stop until he saw decedent fall. When his attention was directed to the point, the engineer never wavered in his testimony that decedent was continuously in his view and in a position to give signals up to the time he was seen to fall and the emergency stop was made.

Petitioner attempts to avoid the effect of this by pointing to statements of the engineer which allegedly contradict his testimony that decedent was continuously in his view. Petitioner relies on testimony and measurements of an expert witness, and upon the fact that the jury was permitted to view the engine and tender, to support the alleged contradiction. As a consequence, it is asserted, the jury was entitled to disbelieve the engineer's version of the accident and to accept petitioner's.

True, it is the jury's function to credit or discredit all or part of the testimony. But disbelief of the engineer's testimony would not supply a want of proof. Bunt $v$. Sierra Butte Gold Mng. Co., $\mathrm{I}^{8}$ U. S. 483,485 . Nor would the possibility alone that the jury might disbelieve the engineer's version make the case submissible to it.

${ }^{120} 340$ U. S. at $575-576$. 
Hence, the opinion pointed out that all the evidence showed was that decedent fell before the train stopped; that, if one did not believe the engineer's testimony that he stopped after-indeed, because of - the fall, then there was no evidence as to when decedent fell; that there would still be a failure of proof; and the opinion concluded saying $:^{\mathbf{1 3 0}}$

To sustain petitioner, one would have to infer from no evidence at all that the train stopped where and when it did for no purpose at all, contrary to all good railroading practice, prior to the time decedent fell, and then infer that decedent fell because the train stopped. This would be speculation run riot. Speculation cannot supply the place of proof. Galloway v. United States, 3r9 U. S. 372, 395 .

Even on that state of facts, the dissenting justices, Black and Douglas, argued that the trial court should have allowed the jury to run riot in just that kind of speculation, asserting their opinion that the taking of this verdict from petitioner is "a totally unwarranted substitution of a court's view of the evidence for that of a jury."131

\section{The I95I Term}

Nothing happened at the I95I Term to throw any doubt on the soundness of the decision in the Moore case.

In Desper v. Starved Rock Ferry Co., ${ }^{132}$ the Court, Mr. Justice Jackson writing the opinion, held that a man employed in the winter in painting, cleaning, and waterproofing boats in a sightseeing fleet of motorboats which were to be used only in the summer months for sightseeing on a river, was not a "seaman" within the meaning of the Jones Act.

Mr. Justice Black and Mr. Justice Douglas dissented.

Dice v. Akron, C. \& Y.R. R., ${ }^{133}$ was a decision by the Court, opinion by $\mathrm{Mr}$. Justice Black, against the railroad on an issue as to an alleged fraudulent release. The Court reversed the Supreme Court of Ohio, which had affirmed a verdict for defendant notwithstanding jury verdict for the plaintiff. Under Ohio law factual issues as to fraud in the execution of a release "other than fraud in the factum" are to be determined by the judge. "Fraud in the factum" is to be determined by the jury. The Supreme Court of Ohio held that the issue involved in this case was not "fraud in the factum" but fraud in the inducement, and, hence, that the judge had the right to and was required to determine the fraud issue notwithstanding the jury's verdict. ${ }^{134}$

The Supreme Court held that this was a federal question, that Ohio law could not control, and reversed on the merits of the decision. Mr. Justice Black again quoted the language from Bailey v. Central Vermont R. R. (3I9 U. S. 350), to the effect that "The right to trial by jury is 'a basic and fundamental feature of our

${ }^{130} I d$. at $577-578$.

${ }^{131} \mathrm{Id}$. at 580 .

132342 U. S. 187 , decided Jan. 2, 1952.

133342 U. S. 359, decided Feb. 4, 1952.

134 155 Ohio St. I85, 98 N. E. 2d 30I (295I). 
system of federal jurisprudence" "; “. . . that it is part and parcel of the remedy afforded railroad workers under the Employers' Liability Act"; and that to deprive railroad workers of the benefit of a jury trial where there is evidence of negligence "is to take away a goodly portion of the relief which Congress has afforded them."135

Justices Frankfurter, Reed, Jackson and Burton concurred in reversal but dissented from the Court's opinion, a recent technique of a "concurring dissent" or a "dissenting concurrence," as the emphasis may be. They did not think that state courts necessarily have to provide jury trials for FELA cases, Minneapolis \& St. L. R. R. v. Bombolis (24I U. S. 2II), having clearly so held thirty-six years ago and having been often cited by the Court but never questioned. However, they thought that the fraud issue raised a federal question, and, since they could not be sure that the trial court had followed the federal test in passing on that issue, they concurred in the reversal.

\section{The r952 Term}

At the time this goes to press there has been only one decision by the Supreme Court at the October Term, I952, falling within the scope of this paper, the six-tothree decision on February 2, r953, in Stone v. New York, C \& St. L. R. R. (73 Sup. Ct. 358). In that case Mr. Justice Douglas delivered the opinion for the majority. There had been a jury trial and a verdict for the petitioner, Stone, in a trial court in Missouri. The Missouri Supreme Court reversed (249 S. W. $2 \mathrm{~d} 442$ (I952)), holding that plaintiff had not made out a submissible case either as to negligence or as to causation. The United States Supreme Court reversed the Missouri Supreme Court.

The case was strikingly like that of Blair v. Baltimore \& Ohio R. R. (323 U. S. 600 , supra). In the Stone case Stone and another employee were removing old or worn track ties. The rails were jacked up, the spikes that held the rails pulled, the tie plates removed, and the ties pulled, usually being pulled with tongs by two men. If there were any old spikes protruding downward from the tie into the ground, three or four men would usually be required to pull the tie.

Stone and his fellow servant were unable to remove a tie because, as it turned out, a spike was driven through it into the ground. The "straw boss" told Stone he was not pulling hard enough. The straw boss then put a bar under the far end of the tie while Stone and the other man pulled again. Still the tie would not come out. The straw boss told Stone to pull harder. Stone said he was pulling as hard as he could. The straw boss then said, "If you can't pull any harder, I will get somebody that will." So Stone, with his fellow servant, gave a hard pull and Stone hurt his back. The tie was finally pulled out by four men-two pulling, one prying with a crow bar, one hammering with a maul.

On these facts the Supreme Court, reversing the Supreme Court of Missouri, held that the case was peculiarly one for the jury, since fair-minded men might reach

${ }^{135} 342$ U. S. at 363 . 
different conclusions as to whether there was a causal connection between the order of the straw boss to pull harder and Stone's back injury.

Mr. Justice Frankfurter, with whom Mr. Justice Reed and Mr. Justice Jackson joined, dissented. Again Mr. Justice Frankfurter paid his disrespect to negligence as the basis of liability in the FELA. He said (73 Sup. Ct. at 360):

However, the central components of liability for negligence-that it rests upon fault and that appropriate causality must be established between the negligent circumstances and the complained-of injury-are the same for actions under the Federal Employers' Act as for any other negligence actions. For reasons that I for one have long deplored, Congress has seen fit to make such a concept of negligence the basis of compensation for inevitably untoward incidents.

I deplore this basis of liability because of the injustices and crudities inherent in applying the common law concepts of negligence to railroading. To fit the hazards of railroad employment into the requirements of a negligence action is to employ a wholly inappropriate procedure-a procedure adequate to the simple situations for which it was adapted but brutally unfit for the situations to which the Federal Employers' Liability Act requires that it be put. The result is a matter of common knowledge. Under the guise of suits of negligence, the distortions of the Act's application have turned it more and more into a workmen's compensation act, but with all the hazards and social undesirabilities of suits for negligence because of the high stakes by way of occasional heavy damages, realized all too often after years of unedifying litigation.

Although the dissenters indicated that they were clear that understanding and fair-minded judges on the Supreme Court of Missouri could have held that the facts of this case were for the jury, nevertheless the dissenters could not say that the Missouri Supreme Court could not, as it did, hold that the plaintiff did not make a submissible case under the Act either for negligence or as to causation. Accordingly, they dissented from the reversal of the Supreme Court of Missouri.

The majority and dissenting opinions in this latest case again leave the law in a state of confusion. The dissenting opinion, indeed, introduces a wholly new test as to whether a case is made for the jury, a test not as to what members of the Supreme Court of the United States would have held if they had been members of the highest court of the State, but whether the highest court of the State has a right to apply its own test, which ought not to be reversed by the United States Supreme Court on its own different view.

The facts in the Stone case were very thin for a holding that a submissible case was made out for the jury. Yet the majority of the Supreme Court reversed the unanimous Supreme Court of Missouri on its holding that a submissible case was not made out.

As the present paper goes to the press there are some dozen additional FELA cases pending at the October Term, 1952, either on petition for certiorari or for argument, none of which has yet been decided. It would not be proper to comment on any of these undecided cases. 
III

ConcLusion

If the decisions since Brady and down to Eckenrode and Moore, particularly such decisions as Tennant, second Tiller, Poff, and Lavender, continue to be followed, then the Supreme Court will have completely undermined the general law of negligence. But if Brady, Eckenrode, Reynolds, and Moore continue to be followed as controlling precedents, then the law of negligence will have been preserved and it will be up to the Congress, not the Court, to determine whether it is wiser to substitute a workmen's compensation insurance law for the present negligence statute.

As Gouverneur Morris used to say succinctly in his Paris Diary, "Nous verrons."

This writer is profoundly convinced that such a decision is a legislative one for Congress, not a judicial one for the Court, however "antiquated" its members may feel a negligence statute to be. 